\title{
History of the Perfume Industry in Greco-Roman Egypt
}

\author{
Dr. Doaa Ragab Fadel* \\ Lecturer in Tourist Guidance department, High Institute of Tourism \& Hotels, King Marriott - Alexandria \\ *Corresponding Author: Dr. Doaa Ragab Fadel, Lecturer in Tourist Guidance department, High Institute \\ of Tourism \& Hotels, King Marriott - Alexandria
}

\begin{abstract}
There's no doubt that in civilizations from Egypt to Greece, fragrance was spread as a vital element in life and death. Egypt was famous for its perfume throughout the ancient civilizations. In ancient Egypt, Alexandria was famous for the manufacture of perfumes and as the marketplace of several Egyptian products, such as myrrh. Mendes too was famous for its perfume.
\end{abstract}

Indeed, perfumes were required for use in temples, rituals, ceremonies and festivals. There were various words in ancient Egypt used to refer to perfume, such as " $n d m . s t$ "(pleasant) and "rdw" (jar). In the temples, large quantities of incense, perfume and scented flowers were offered to the gods. Some gods were linked with specific scents, such as Anubis god, who anointed the mummy with sacred oils to prevent the body from decaying.

Besides, the ancient Egyptians used perfumes in many different forms to give an agreeable odor to the body. In particular, flowers and spices such as cinnamon and myrrh added fragrant scents to perfumes and oils used in everyday life.

In other words, recipes for and depictions of perfume preparation can be found in numerous ancient temples, while the recipes for perfumes were inscribed on the walls of the laboratories of the Ptolemaic temples. Theophrastus, the Greek philosopher, talked about the ways used to color perfumes and scents, such as the pigmentation used for red perfumes, which was alkanet from the plant Anchusa. Two Greek Kyphi "burnt substance" recipes mentioned lists of ingredients for perfumes.

Further, the perfumes were made from mixtures of several ingredients and three techniques seem to have been used; the substances were pounded, mixed together, and then put on the fire. Also the ancient Egyptians used several kinds of herbs and plants to produce perfumes, such as iris. Iris root or balsam was used as a base for the ancient perfumes. While the most fragrant oils in ancient Egypt were myrrh, frankincense and lily, which were mixed with essences of flowers, fruits and herbs.

Key words: Perfume, incense, cone, fragrance, recipes, scene, offering, container, Greek, Roman, oil, cosmetics, production, laboratory

Research Methodology: Meanwhile this paper depended on the historical and artistic sides of perfume industry through Greco-Roman times as well as analyze and study the impact of perfume usage at recipes of perfumes and perfumes' inscriptions at the temples and tombs, whether at daily life or religious ceremonies.

Specifically, this research contained scenes of the ingredients of perfumes in the temples and tombs in GrecoRoman Egypt focus on the laboratory in the temples, where incense and perfumes were prepared and stored as well as offering scenes of the Ptolemaic and Roman. While it was hardly ever included perfumes workshop in the tombs because of the space to contain any laboratory of workshop inside the tombs.

\section{INTRODUCTION}

Further throughout the history of both Eastern and Western civilizations, perfume has marked societal customs related not only to everyday life but also rituals for the gods and for guiding the deceased to the afterlife, such as the use of smoky odors to signify the divine or deified bodies (Tatomir, 2016). Thus, cosmetics' usage has been widespread as a part of daily life and religious rituals (Voudouri's \& Tesseromatis, 2015). Also oils in Egypt were of vital importance against the drying heat of the sun, arid winds and hot air of the Nile Valley (Ruiz, 2001).

Additionally, Perfumery is the art of collecting all the various fragrant essences (Heuze, 1862). There were several stages to producing perfumed substances, from cultivating the flowers, to storing oils into jars (EL-SHIMY, 2003). In the meantime, cosmetics and perfumes were an important part of life 
for both sexes in ancient Egypt (Redford, 2001), making it an essential industry (Lesko, 1987). Besides the Egyptians made a great variety of ointments for the hair and body) (Heuze, 1862). As well as, it was considered a suitable amusement for those attending feasts and, while eating, they would anoint themselves, or put on new necklets and exchange flowers (Erman, 1971).

Currently, perfume was a major state industry, occupying a central role in Egypt's economy (Lesko, 1987). Also they were discovered in Mesopotamia and Egypt, and constituted a significant part of rituals, beauty and commerce (Voudouri \& Tesseromatis, 2015). The use of perfume has been identified from as far back as the Predynastic period in Egypt, but most of the surviving recipes for perfume date from the Greco-Roman period (EL-SHIMY, 2003).

In addition, in ancient Egyptian civilization, scent or perfume was used to epitomize authority and divine sanction, acting as a powerful symbol. Therefore, aroma played a prominent and well-known role in their magic, religion and medicine (Tatomir, 2016). Due to the perfumes of ancient Egypt consisted chiefly of fragrant oils and fats (ointments), the use of which is mentioned frequently in ancient texts and by several Greek and Roman writers (Lucas \& Harris, 2012;Toller, S., \& Dodd, 1993). Not only, had the ancient Egyptians specialized in perfume production in the Ptolemaic period, but also they exported perfumes all over the Mediterranean (Byl, 2012). Besides the Romans used dry perfumes to scent their clothes, a custom still prevalent among modern Greeks (Heuze, 1862).

\section{History of Usage of Perfumes in AnCient Egypt}

In the past, Egyptian perfumery was famous across the Mediterranean (Voudouri \& Tesseromatis, 2015). As well as Pliny states that Egyptian perfumes were famous throughout the ancient world and the classical authors knew and wrote about them (Byl, 2012). Also the art of perfume preparation is said to have been born in ancient Mesopotamia and Egypt, and later refined by the Romans and Persians (Gadea, Vatca, \& Vatca, 2017).

Likewise, perfume was not only an expensive luxury, but a valuable export (Ruiz, 2001) and used by the ancient Egyptians for three distinct purposes, offerings to the gods, embalming the dead, and uses in private life (Heuze, 1862), as follows: First, priests offered sweet scents to the gods three times a day (Northrup, Bentley, Jr, Manning, Pomeranz, \& Topik, 2004). According to Homer, the Olympian gods taught people the secrets of perfume making and use, and it appeared in many scenes of Greek mythology (Gadea, Vatca, \& Vatca, 2017). Second, perfume was essential to ensure the rebirth of the deceased and a successful afterlife for him/her (Byl, 2012), therefore perfumes were used in the mummification process as well, with sachets often placed around the neck of the deceased person (Northrup, Bentley, Jr, Manning, Pomeranz, \& Topik, 2004). Third, in private life, the ancient Egyptians used perfumes on their hair and bodies (Butler, 2000), and in ritual and celebratory situations, religious sacraments, marriage, funerary ceremonies and festive dinners. As well as being used by athletes, aristocrats, politicians and royalty, they served as medicinal agents (Voudouri \& Tesseromatis, 2015). In ancient Egypt, sacred writings were read to perfume holders as well as the Egyptian prescriptions were a mixture of perfumes were displayed in balls and burnt on hot coals to release the perfume (Veiga, 2009; Lesko, 1987).

In the times of Old Kingdom of ancient Egypt, specialists were in charge of the king's oils that were provided for use in the other world and kept in an "unguent chamber" (Manniche \& Forman, 1999). Also, from the early New Kingdom to the Ptolemaic period, some representations of the ancient Egyptians show them wearing cones on their heads (Stevens, Rogge, Bos, \& Dabbs, 2019). The cones were symbolic representations of the invisible perfume worn by the banqueters (Price, 2018) and guests, both female and male, in banqueting scenes (Stevens, Rogge, Bos, \& Dabbs, 2019) (Fig.1-2). For instance, there was a representation shows men and women with cones in their hair, which were made of solid perfume in the form of scented wax (Lacovara, 2016). On special occasions, the ancient Egyptians were perfuming the body and garment with a sticky, sweet and aromatic fragrance (Ruiz, 2001). For instance, wax cones have been discovered in Amarna that are thought to be symbols of rebirth, fertility and the afterlife (Stevens, Rogge, Bos, \& Dabbs, 2019) (Fig.3). Also, perfumed substances were used in the preparation of the head of the deceased (Strong, 2018). 


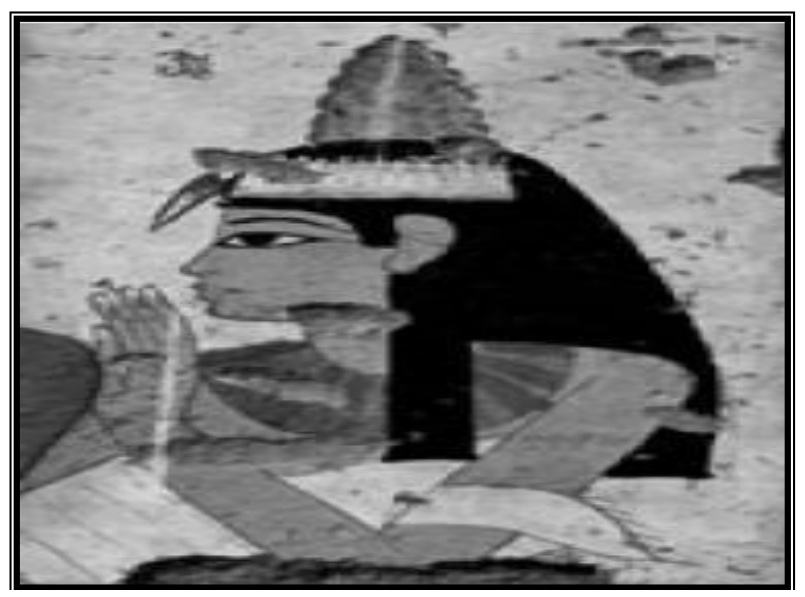

Fig1. A lady with her cake of ointment (Voudouri \& Tesseromatis, 2015).

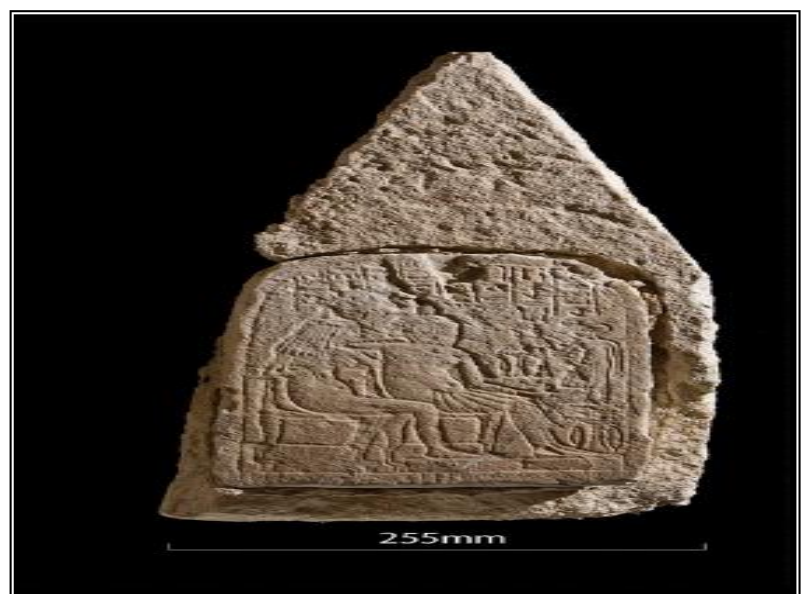

Fig2. Funerary Stelae from the south tomb cemetery from Amarna showing a seated man and woman wearing head cones (Stevens, Rogge, Bos, \& Dabbs, 2019; Erman, 1971).

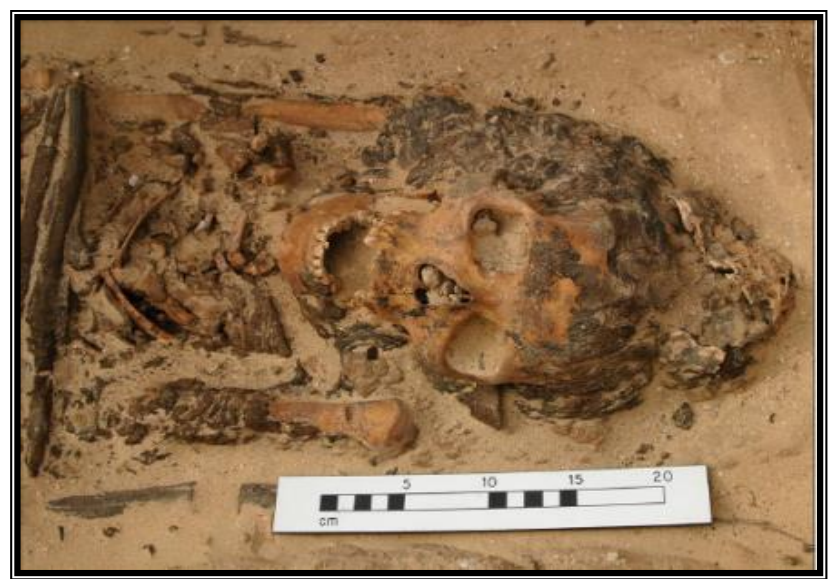

Fig3. Cone on the head of an individual of the Amarna (Stevens, Rogge, Bos, \& Dabbs, 2019).

In other word, the Greeks and Romans adopted the use of perfumes from the Egyptians (Northrup, Bentley, Jr, Manning, Pomeranz, \& Topik, 2004) and Egyptian perfume was appreciated in classical Greece, as indicated in Athenian texts (http://www.britishmuseum.org/Naukratis). For instance, The Greeks in general did not enjoy perfume on a wide scale until the fourth century B.C., when the civilization was at its height (Northrup, Bentley, Jr, Manning, Pomeranz, \& Topik, 2004).

Further Greece played a major role in the history of perfumes, not only through art, but also everyday life (Gadea, Vatca, \& Vatca, 2017). Also the Greeks used the perfumes at all their public festivals, where fragrant waters perfumed and refreshed the air (Heuze, 1862). While they loved the perfumes (Butler, 2000), not only offering them in their religious ceremonies as homage to their gods, but also looking upon them as a sign of their presence (Heuze, 1862). As well as the Greeks cremated their dead, and the bones and ashes were afterwards washed in wine mixed with perfumed ointments 
(Butler, 2000). Following the Egyptian advancements, the ancient Greeks evolved the art of cosmetics and perfume creation while developing and promoting their trade (Voudouri \& Tesseromatis, 2015).

Besides Alexander the Great favored the perfume trade of the East and made incense even more widespread in Greece (Voudouri \& Tesseromatis, 2015) such that the Egyptian influence became prevalent during that time (Rhind, 2014). Therefore, the perfume industry reached its heyday in Ptolemaic Egypt (Voudouri \& Tesseromatis, 2015). For example, Queen Cleopatra greeted her Roman lover Antony in a ship with perfumed sails, her chambers strewn liberally with rose petals, so that the Egyptian legacy of perfume reached Roman culture via the Greeks (Rhind, 2014).

Clearly the traditional Roman use of perfumes remained limited up until the expansion of the empire, throughout which Rome then exported perfumes and oils (Northrup, Bentley, Jr, Manning, Pomeranz, \& Topik, 2004). In the same way perfumes were used in daily personal rituals in Roman times, such as in makeup, skin care and personal hygiene routines (Rhind, 2014). In the meantime, the Romans adopted the funeral rites practiced by the Greeks (Butler, 2000), and variations of the perfume cone were used by both ancient Greek and Roman ladies (Voudouri \& Tesseromatis, 2015). Also Caligula spent enormous sums on perfume and plunged into perfumed baths after his excessive orgies (Butler, 2000) (Fig.4).

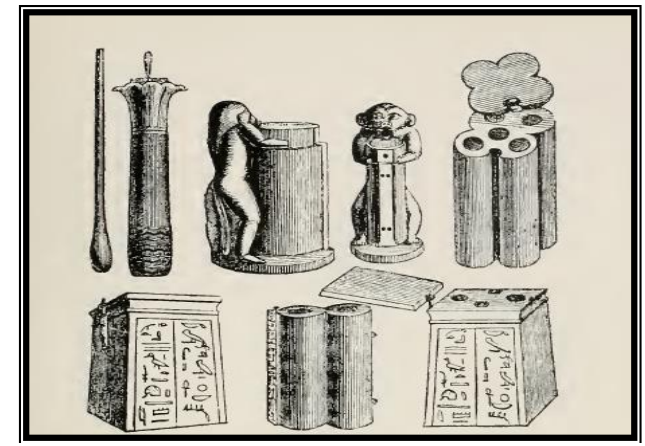

Fig4. Toilet boxes for holding cosmetics, such as Kohl for the eyes, Henna for the fingers, and perfumed oils for anointing the body after a bath (Gosse, 2007).

Thus, oils featured in rituals, served protective functions, and demonstrated family wealth, but also served cosmetic purposes (Wilfong, 2013; Brier, 2013; Strong, 2018).

\subsection{History of Perfume-Producing Cities}

Besides the Egyptians produced perfume in Mendes and Alexandria during the Ptolemaic period, exporting to Rome and other cities on the Mediterranean Sea (Byl, 2012; David, 2007).

\subsubsection{Mendes}

Specifically, the 'Mendesian', named after the Egyptian Delta city of Mendes (Byl, 2012) located on the Mendesian branch of the Nile (Bard, 2005) was considered the most excellent perfume in the ancient classical world (Byl, 2012). Therefore, it's possible that the precious ancient ruins of Timaiwas underneath the large city but inaccessible to archeologists (Zermani \& Nawar, 2015) (Fig.5).

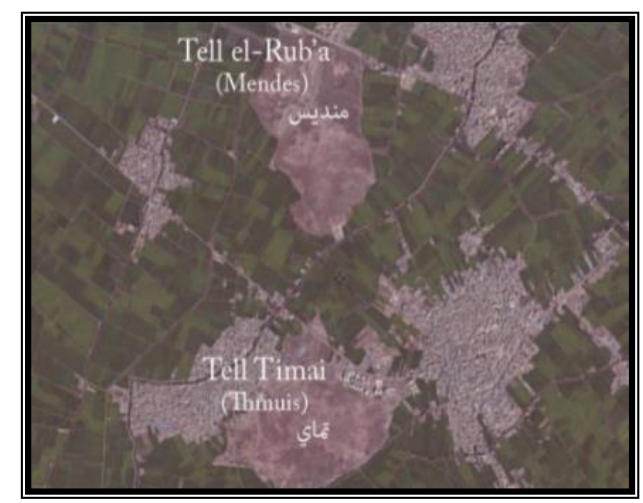

Fig5. Map of Mendes and Timai (Zermani \& Nawar, 2015). 
As well as the type of pottery in Mendes that was used to make the large mixing vats were Hellenistic in style, thus dating from the $3^{\text {rd }}$ or $4^{\text {th }}$ century B.C, for example, Queen Cleopatra considered Timai's perfume her special perfume. Additionally, there were shards of ceramic perfume bottles and amphora were found in Mendes. Queen Cleopatra considered Timai's perfume her special perfume (Zermani \& Nawar, 2015; David, 2007).

\subsubsection{Alexandria}

In addition, Alexandria's location made it the most important trade center of the Mediterranean region, a place where luxury goods such as perfumes were imported from the East, either stopping in Alexandria or passing through the city on their way to somewhere else (Escoffey, 2012). In the meantime, Alexandria was famous for the manufacture and perfection of perfume, and various types were widely used in the Pharaonic period (Green, 1996).

\subsection{Names of Perfumes in Ancient Egypt}

Indeed, the term "perfume" can be used to describe the oily extract of a plant, and derives from the Latin word "perfumum" which was used to describe scent mixtures conveyed by smoke (Voudouri \& Tesseromatis, 2015; Gadea, Vatca, \& Vatca, 2017). Also the Egyptians used words for the act of smelling such as tpj "sniff", hnm "to smell or breath", and stj "odor, smell or perfume" (Price, 2018). Meanwhile, the Egyptians used two general words for perfume: the first was $n d m . s t$, derived from " $n d m$ ", meaning "pleasant", while the second was $r d w$, derived from " $d w$ ", meaning "liquid", as well as two terms for different kinds of perfumes: "the Egyptian" and "eye of Horus" (Byl, 2012).

While there was connection with the words of $s t 3 t$ "lotus" and $h 3 w$ "flower" 1 i. In other word,

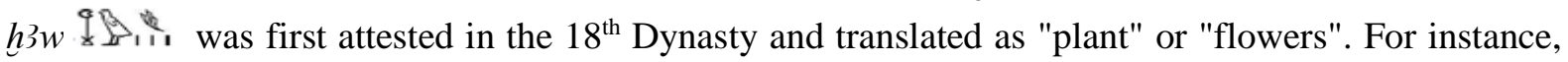
some scenes of the word $h 3 w$ "flower" in the tomb of Petosiris as well as appear in Greco-Roman texts found at the Dendera and Philae temples (Strong, 2018).

\subsection{Relationship Between Perfumes and Gods in Ancient Egypt}

Further the gods had favored Egypt with the production of floral fragrances (Manniche \& Forman, 1999). Additionally, the deities of ancient Egypt were all fragrant beings, so cult statues were anointed with perfumed oil in the daily temple ritual (Byl, 2012). Therefore, the daily worship was performed by the priest and the sacred chapel was cleaned and filled with perfume (Erman, 1971) to anoint the sacred images (Lacovara, 2016). In addition, with some figurines or statuettes, perfumes were used to induce a deity to manifest itself in the temple (Pinch, 1994).

In the meantime, in Greece, according to the Homeric tradition, Olympian gods taught people about the use of perfumes (Voudouri \& Tesseromatis, 2015). During the Ptolemaic period, cloth, which was part of the divine essence, was offered along with perfume to the deities (Byl, 2012). While, floral wreaths were worn as crowns for religious festivities, in both the Egyptian and the Greek and Roman worlds (Riggs, 2006). Thus, perfume use was a part of Greek hospitality and social and cultural practices (Voudouri \& Tesseromatis, 2015).

Besides Shesmu god was lord of the perfume and Hathor goddess was connected with perfume in its various forms. Also, Nefertum god was considered lord of perfume (Byl, 2012) and oil makers because he was born of the fragrant blue lotus (Lacovara, 2016). While, during Apis god's lifetime, it was perfumed each day. Further, Bastet goddess's name is written with the bas jar (bs) and a loaf $(t)$, that is a vessel and holds perfume associated with her festivals (Remler, 2006). In addition, Hathor goddess was the mistress of myrrh, which links her to banquets, where perfume, in the form of unguents containing myrrh and liquid perfume, was used (Byl, 2012). In other word, the Greeks considered the goddess Aphrodite hid and bushed of myrtle tree flowers, while the Romans considered the myrtle became a symbol of Venus goddess and marriage as well (Voudouri \& Tesseromatis, 2015). Illustrated by, a scene in the Louvre museum, the god Osiris is depicted as Anubis god, with outstretched arms, behind a mummiform figure with a perfume cone and lotus blossom upon his head (Scalf, 2014) (Fig.6). 


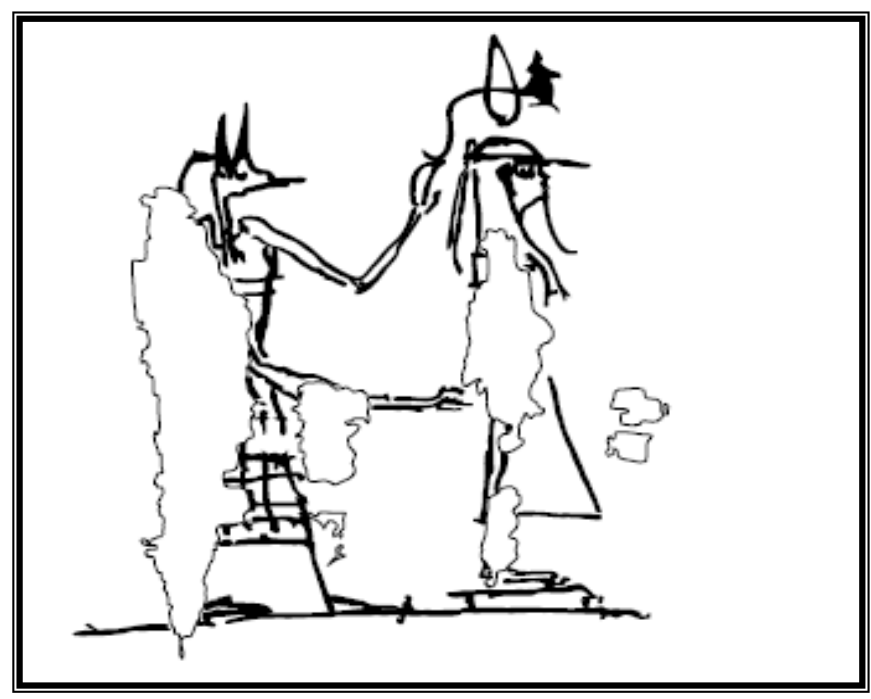

Fig6. Scene of presentation of mummy, Louvre Museum (Scalf, 2014).

\subsection{Ingredients of Perfume Production in Ancient Egypt}

Currently ancient Egypt was the center of production for many exotic and luxury perfumes (Byl, 2012), but the lack of variety of flowers in Greece meant that, like the Egyptians, they had to import ingredients and then manufacture the perfume in their country (Northrup, Bentley, Jr, Manning, Pomeranz, \& Topik, 2004). While from the $6^{\text {th }}$ century onwards, the ancient Greeks imported palm oil, lily, lotus and dill from Egypt (Voudouri \& Tesseromatis, 2015).

Also perfumes are named in the earliest offering lists in the pyramid texts, as well as in tomb and coffin inscriptions and funeral papyri (Butler, 2000). Further the Egyptians used many kinds of perfumes (Erman, 1971), which were concocted from oils derived from plants, animal organs and the fat of such animals as the ox, goose, cat, hippopotamus and crocodile (Ruiz, 2001). While sometimes cinnamon, cardamom, myrrh, honey, wine, or flowers were used to create fragrances (Remler, 2006; Watts, 1998).

Besides plant dyes were an important part of the aromatic ingredients from flowers that were incorporated into oils and fats for use in perfumes (Janick, 2002). Indeed, perfumes were divided into oils and solid perfumes, incense, perfumes in the form of unguent cones, and sacred unguent oils (Byl, 2012). In the meantime, scholars can reconstruct the ingredients and raw materials of the Pharaonic, Greco-Roman perfumes from images found in tombs and from recipes (Redford, 2001) (Fig.7).

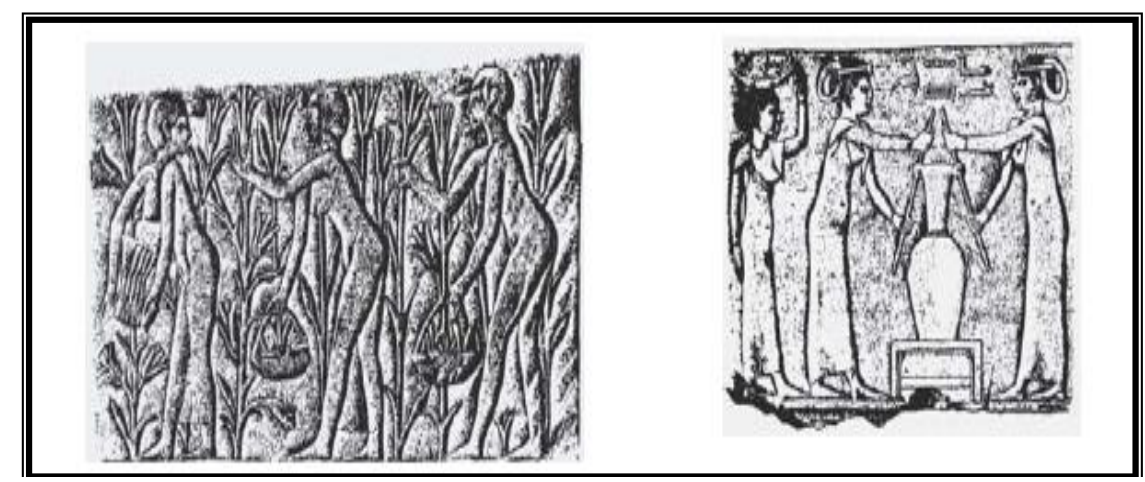

Fig7. Scene depicting the gathering of lilies and expressing of oil of lily for perfumes (Janick, 2002).

In other word, perfumes were created from various parts of plants: flowers, leaves, twigs, roots, wood, fruits, and gum (Butler, 2000), which could be mixed together using three different methods: the first was to immerse the flowers, the second to soak the flowers, fruits, and herbs in boiling oil, and the third resembled the method used for manufacturing wine or oil (Fayed, 1998), examples including Susinon which was made from lilies and Kypros, made from bergamot, mint, and thyme (Butler, 2000).

In particular, the word "seshen", meaning lotus, occurs in a recipe found in the Edfu temple for use during ceremonies for the opening of the mouth (Manniche \& Forman, 1999), while the Egyptians 
attributed specific symbolisms to the iris plant, such as power. Thus, it was used by their kings, while iris parts were placed on the face of the sphinx. While one of the perfumes that was most well-known to the Greeks was Kyphi (Erman, 1971), believed to be a mixture of 16 aromatic resins (Butler, 2000). As well as the name Kyphi is the Latin version of the Greek transcription of the Egyptian word Kapet, originally meaning any substance to be burnt (Byl, 2012). Meanwhile, Kyphi was used in great quantities in the temples, and the recipes were recorded in stone on the walls of the buildings (Manniche \& Forman, 1999), showing that myrrh, broom, frankincense, and several other ingredients were used to make it (Erman, 1971).

In general, recipes were written not only in Greek, but also in Egyptian hieroglyphs (Manniche \& Forman, 1999). Indeed, relief paintings in ancient Egyptian art throughout the Ptolemaic period show that specific recipes were inscribed in hieroglyphs on the walls of perfume "laboratories" located in temples (Byl, 2012). At that point, Theophrastus, Pliny, and Dioscorides relate various recipes for perfumes, such as the sweet perfume of marjoram that was painted with a dye, a root imported from Syria (Voudouri \& Tesseromatis, 2015). In the past, the Romans devised containers for their perfumes, which could be in solid, liquid, or powder form (Butler, 2000).

\subsection{Scenes Showing Perfume in Ancient Egypt in Temples and Tombs}

\subsubsection{Temples}

Currently in the early Ptolemaic period, temples were allowed to produce oil for their own use, but not to sell (Willy, 2010). While Greco-Roman temples had smaller rooms used as storerooms for cultic equipment (Shafer, Arnold, Bell, Finnestad, \& Haeny, 2005), and for the preparation of incense and perfumed oils (Byl, 2012), which were used for the morning rituals of the temple, such as to anoint the god with oils (Shafer, Arnold, Bell, Finnestad, \& Haeny, 2005) and for the ritual of opening the mouth, which was mainly a ritual for the consecration of divine statues (Quack, 2013). Also the statues of the god were purified by libation and censing and by the presentation of pellets of Natron and incense for purifying their mouths (Fairman, 1954). As well as, in the Ptolemaic period, perfumers' workshops were linked to larger production centers containing grain mills, breweries, bakeries, and weaving shops (Byl, 2012).

Specifically, there are two chambers at the Edfu and Dendera temples, called the treasuries of the temples, one of which was the laboratory used to prepare the perfume or anoint the statues of the gods (Mariette, 1890). In the meantime, Instructions for the preparation of Kyphi and lists of ingredients were found in inscriptions on the walls at the temples of Edfu and Dendera (Veiga, 2009). Aspalathos is an ingredient in the three Kyphi recipes written in Greek and in the recipes carved on the walls of the temples of Edfu and Philae (Manniche \& Forman, 1999). For example, in many reliefs, women are represented with their husbands; the women are holding lotus flowers (a symbol of love) and are shown as perfumed (Carolyn, 2010).

\subsubsection{Edfu Temple}

Beyond the hypostyle hall (Fairman, 1954), there are two chambers on the eastern and western sides for storing liquid and solid offerings (Wilkinson, 2000), the walls of which are inscribed with lengthy recipes for the preparation of perfumes (Fletcher, 2010). Additionally, at the northwest corner of hypostyle hall was the Laboratory, where incense was prepared and stored (Fairman, 1954) (Fig.8). For instance, the perfume laboratory in Edfu temple has a recipe carved in hieroglyphics on its walls (Byl, 2012), describing how incense was to be made (Weeks, 2005) for the preparation of perfume for anointing the goddess Hathor (Byl, 2012). Also another such recipe can be seen at the top left of the rear wall (Weeks, 2005).

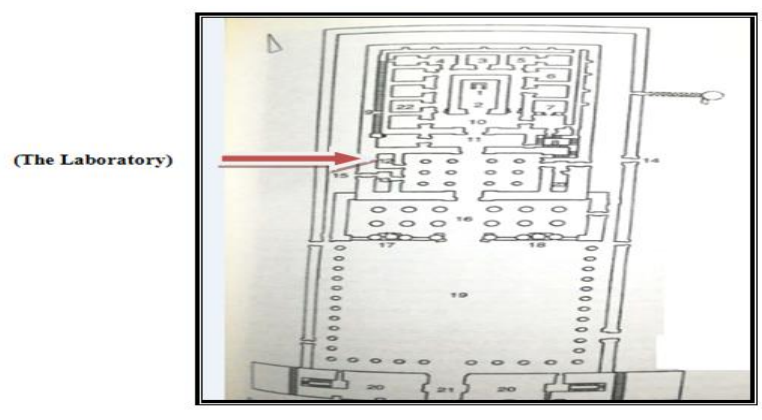

Fig8. Plan of Edfu temple, showing the laboratory (Shafer, Arnold, Bell, Finnestad, \& Haeny, 2005). 
Some of the scenes found in the laboratory of Edfu temple include the following:

Clearly details of perfume preparation are inscribed on the walls of the laboratory of Edfu temple (Manniche, Perfume, 2009) (Fig.9).

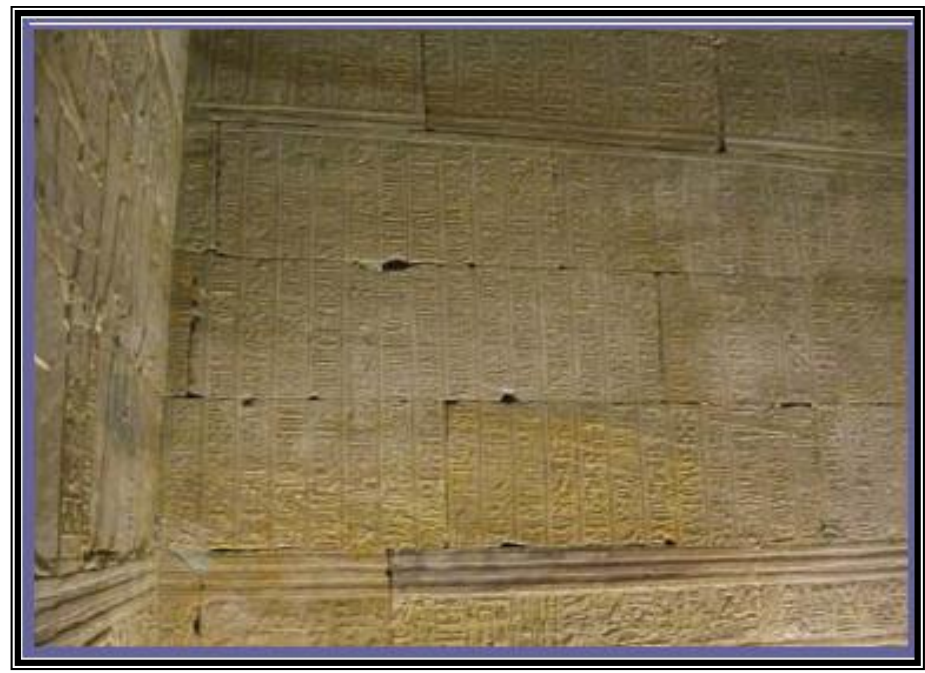

Fig9. Recipes for scents as recorded in the laboratory of the temple of Edfu (Manniche, Perfume, 2009).

(1) On the exterior lintel

As with Ptolemy VI Philometor, with Cleopatra II standing behind him, is making offerings to the seated Edfu triad of deities, Horus, Hathor, and Harsomptus (Byl, 2012) (Fig.10).

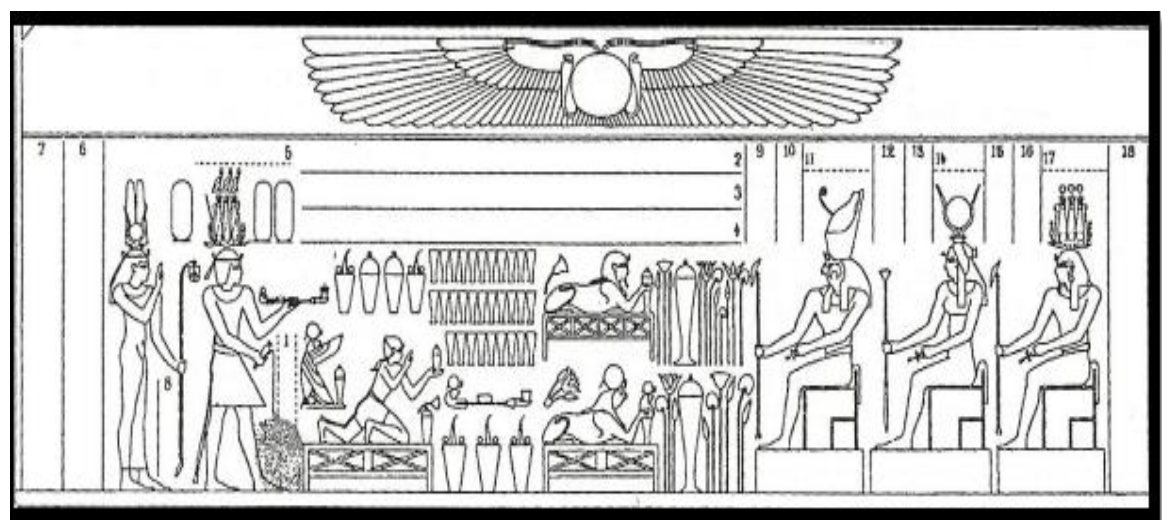

Fig10. An offering scene on the exterior lintel of the laboratory (Byl, 2012).

(2) On the north wall

Likewise, on the left side, Ptolemy VI is offering a statuette of a sphinx with a jar of perfume to Horus and Hathor while, on the right side, he is offering a jar of perfume to Horus and Hathor (Byl, 2012; Quack, 2013) (Fig.11).

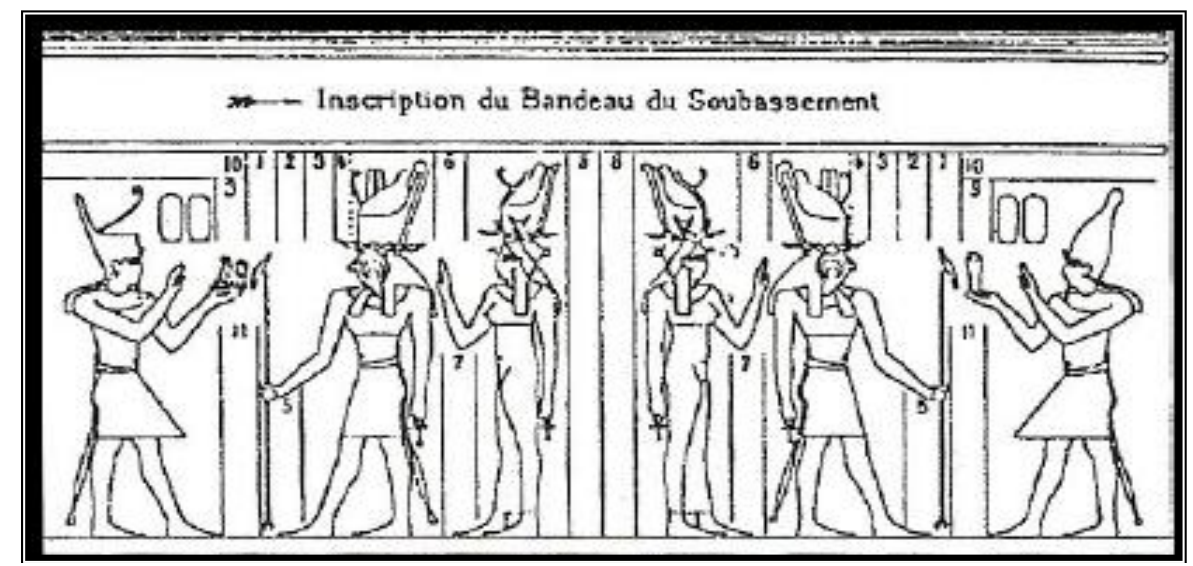

Fig11. Drawing of the frieze at the bottom of the north wall (Byl, 2012) 
(3) There is a formula on the lintel on the eastern part of the central hall of Edfu temple that is as follows:

Title and Formula:

hlnk irp

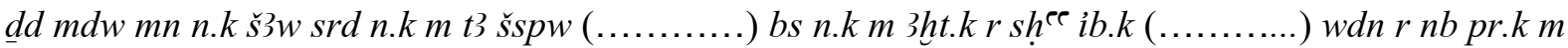
snty.f

Words spoken, "take to yourself vines growing for you in the land, Shepsu plants (..........). Pouring out for you from your eye to make your heart glad (..........) offered to the lord of your house with its perfume" (Metwally, 2009).

\subsubsection{Philae Temple}

Besides, the Ptolemaic rulers provided Philae with its presumed laboratory (Fletcher, 2010) (Fig.12). For instance, the temple of Isis has a perfume and incense laboratory at the south end of the east colonnade but the walls have no texts or reliefs inscribed on them. As well as there is a relief depicting King Ptolemy XII offerings jars of perfumed oils to the goddess Ma'at (Byl, 2012) (Fig.13).

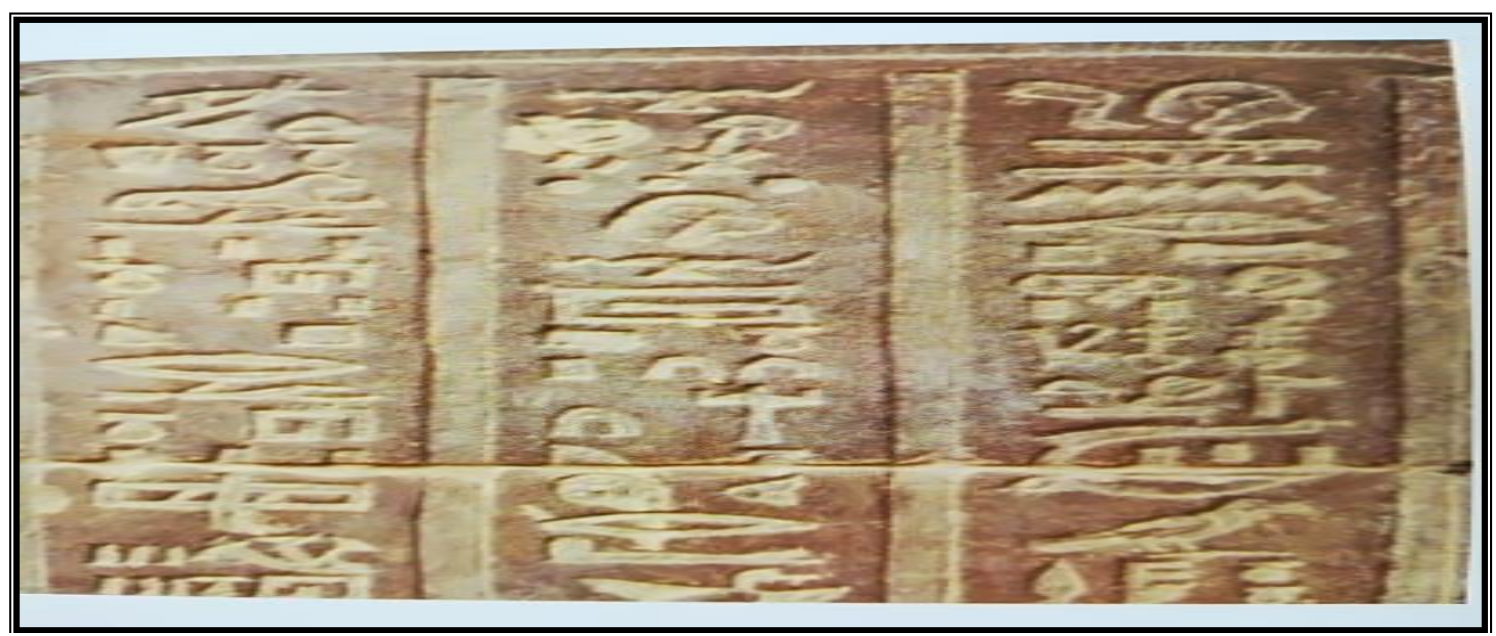

Fig12. Part of a Kyphi recipe. Inscription on a door jamb at Philae, $2^{\text {nd }}-1^{\text {st }}$ century BC (Manniche \& Forman, Egyptian Luxuries: Fragrance, Aromatherapy, and Cosmetics in Pharaonic Times, 1999)

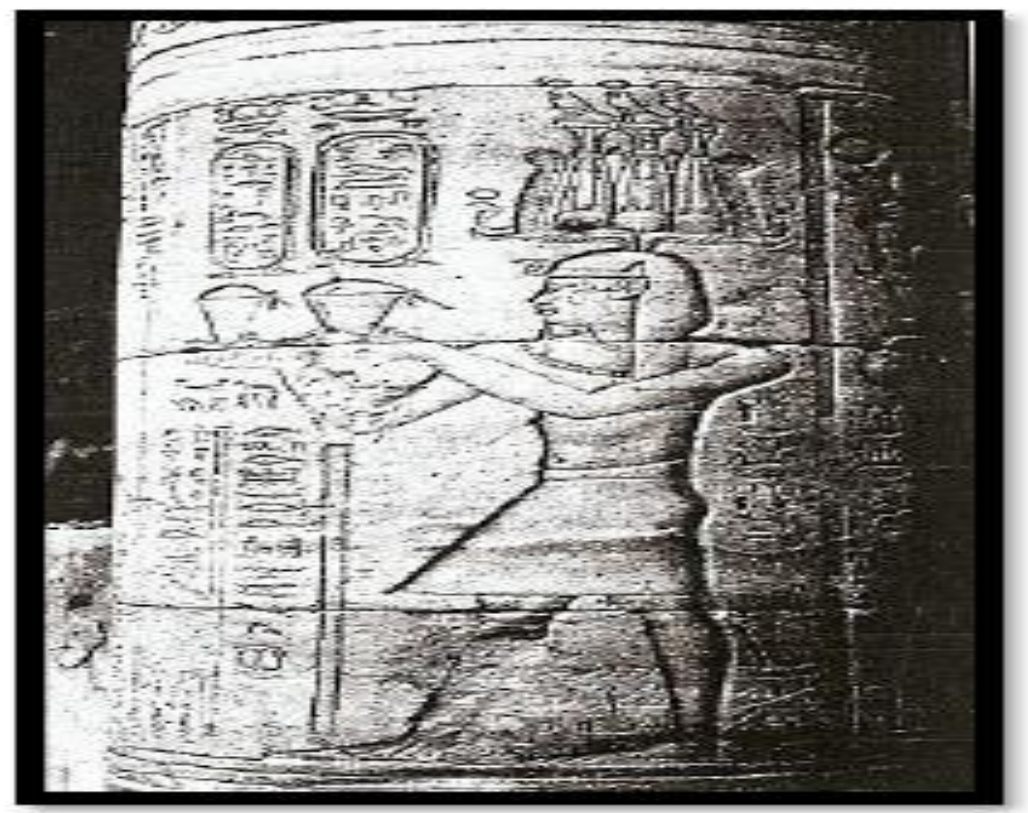

Fig13. Offering scene on a column outside entrance to laboratory (Byl, 2012).

Specifically, a visual representation of the fragrance from essential oils being extracted from an herb can be seen in the Philae temple (Janick, 2002) (Fig.14). 


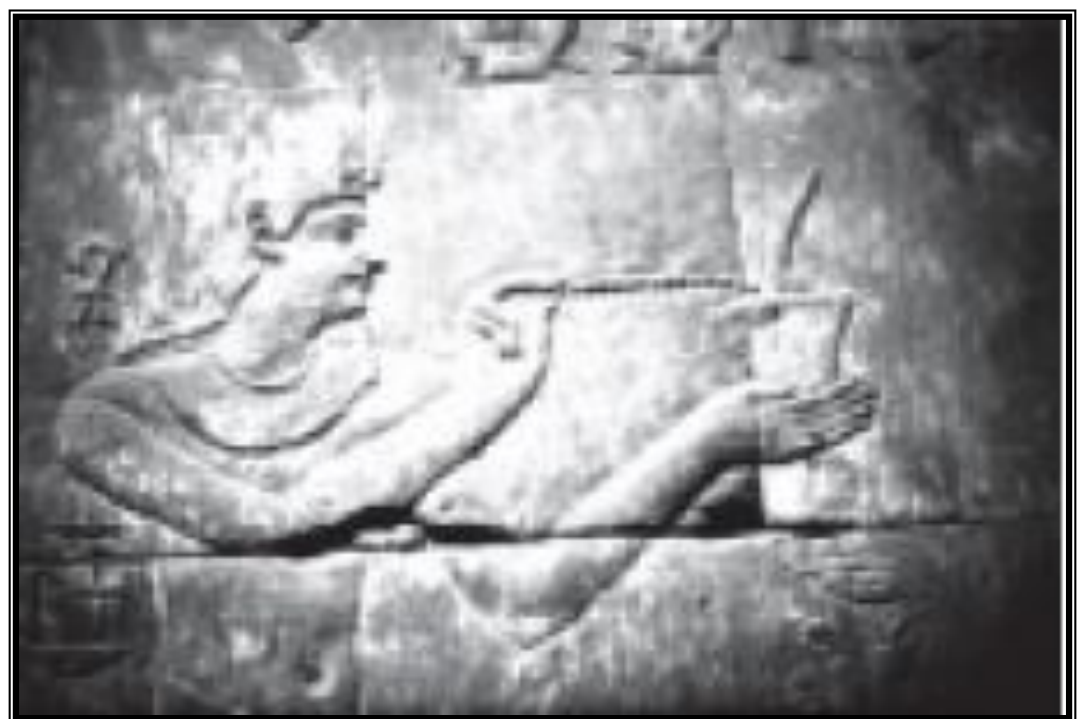

Fig14. Scene showing the extraction of oils from a herb (Janick, 2002).

\subsubsection{Dendera Temple}

At that point, around the hypostyle hall, there is a small chamber for the king to offer incense to the goddess Hathor (Weeks, 2005) (Fig.15). While, in the east wall, Pepi I offers $p \underline{d}$ (incense) and sty (perfume) to several gods, such as Nekhbet and Hathor (Richte, 2012) (Fig.16).

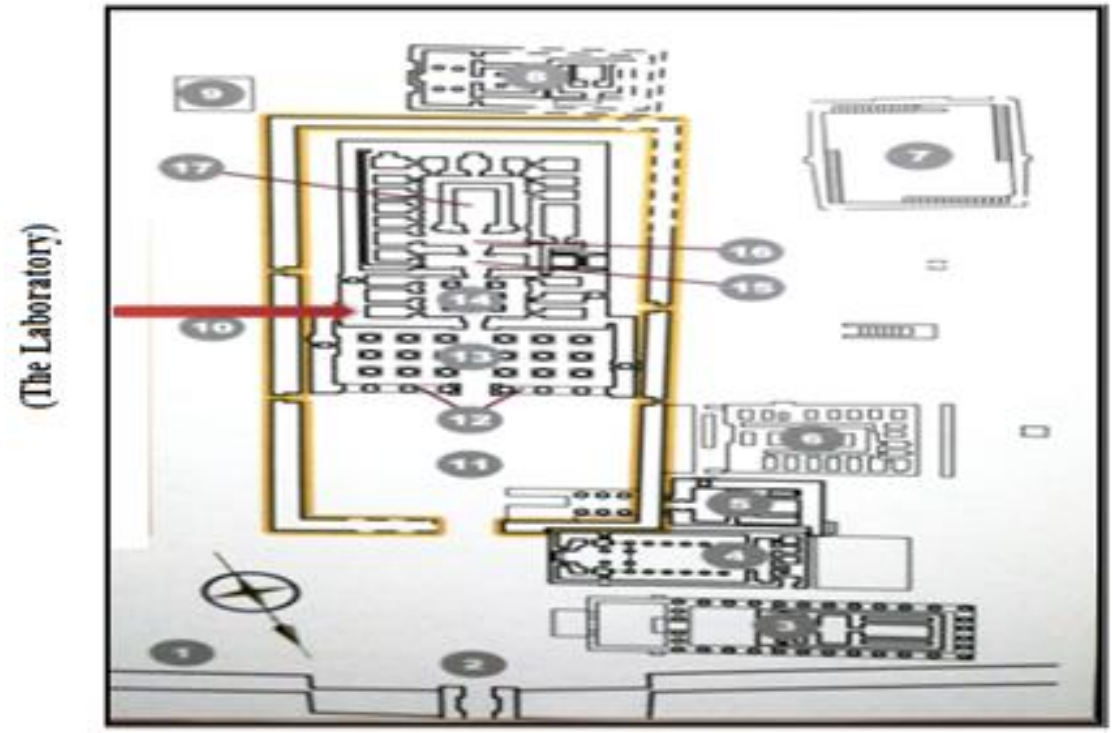

Fig15. Plan of Dendera Temple, showing the laboratory (Weeks, 2005).

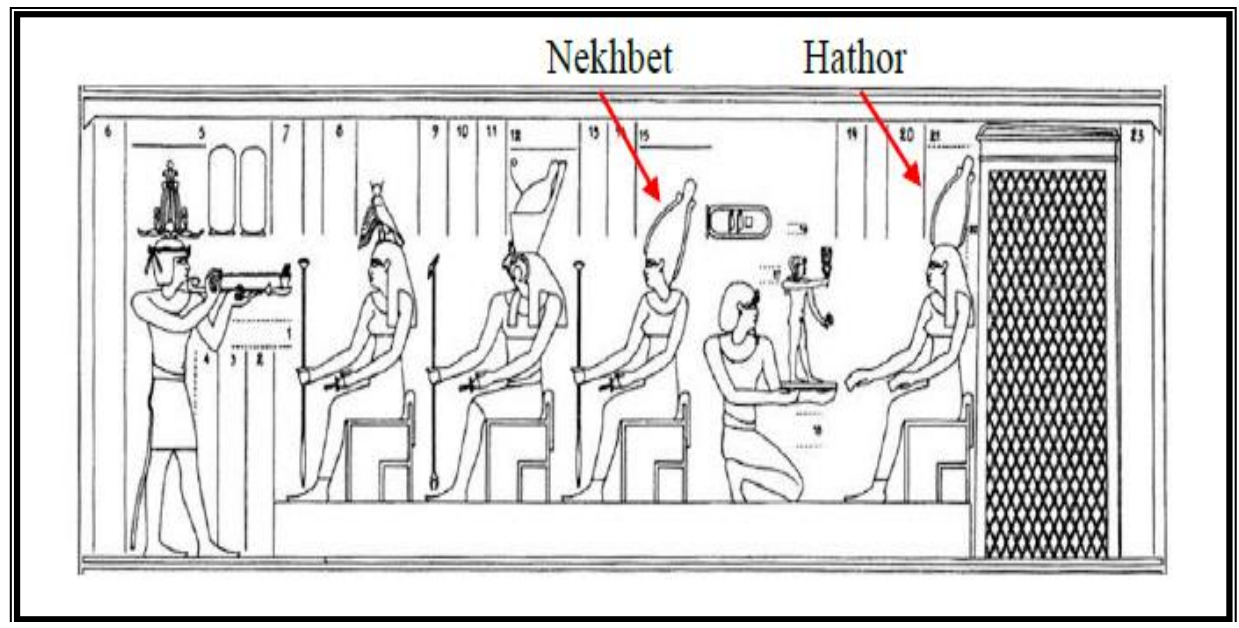

Fig16. $3^{\text {rd }}$ register, east wall of laboratory (Richte, 2012). 
At that point, in the upper register of the north wall of the laboratory, the king, Caesar Augustus, is offering perfume in a sphinx-shaped vessel to Hathor and Horus, after which the god Shesmu with the lion head is offering two jars of perfume (Fig.17). Also, in the lower register, Caesar Augustus is censing before Hathor and he is followed by Nebtneteru offering vessels of perfume (Byl, 2012; Metwally, 2009; Murray, 2002; Hawass, 2000) (Fig.18).

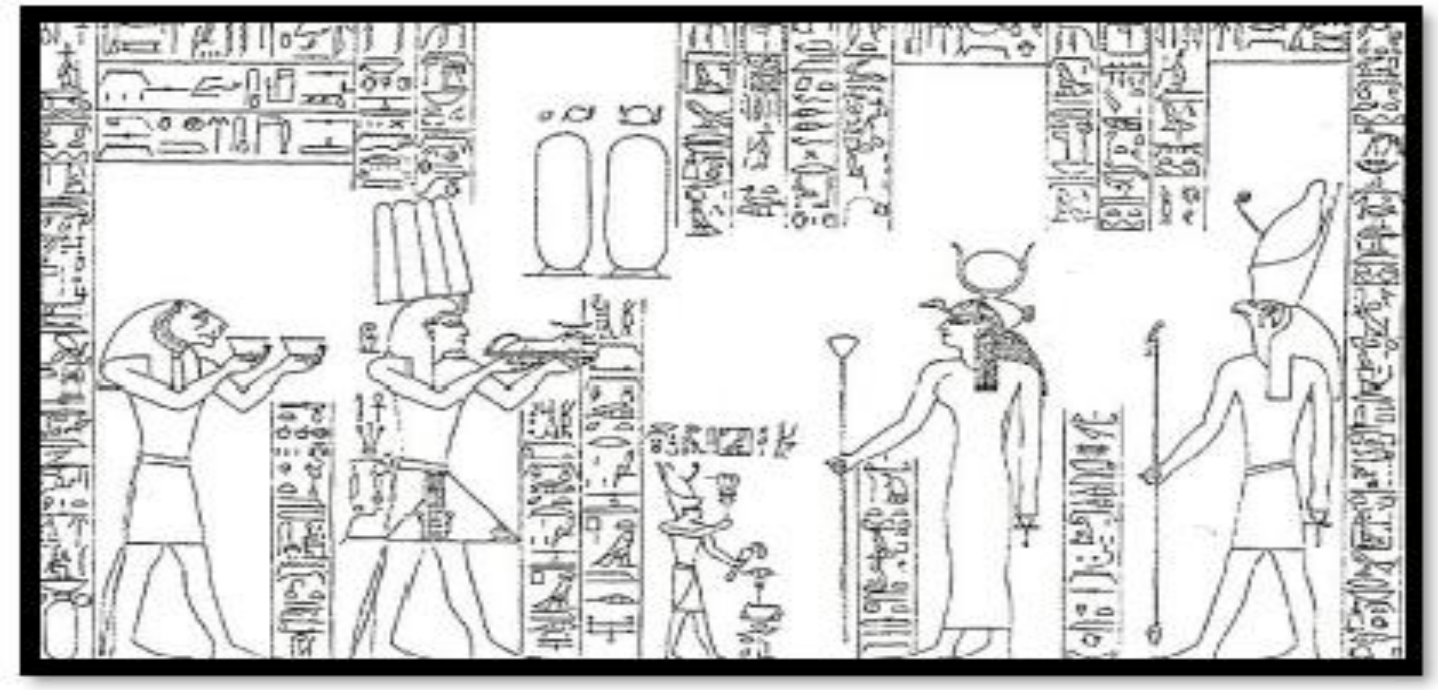

Fig17. Offering scene of Caesar Augustus on upper register on north wall of laboratory (Byl, 2012).

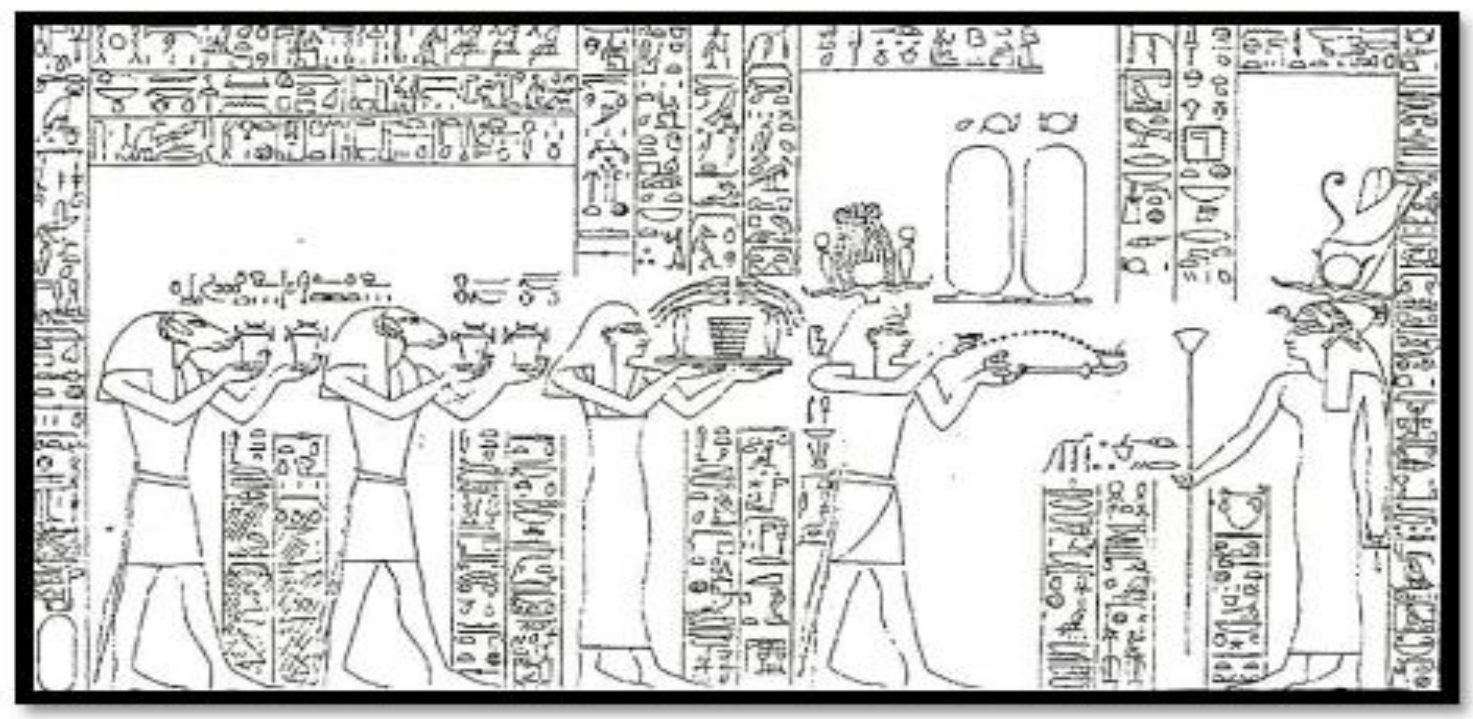

Fig18. Offering scene of Caesar Augustus on lower register on north wall of laboratory (Byl, 2012).

The following formula can be seen on the $2^{\text {nd }}$ register of the south wall:

hr sm $r$ id.t hr rdi.t id.t-ntr $n$ hr.t-tp

"Clothing with perfume giving the divine perfume to the uraeus".

Another formula can be seen on the $3^{\text {rd }}$ register of the east wall:

$n \check{s} p$ fnd $=$ tn $m$ sty $=f m-n=$ tn ir.t hr ii sty $=s r=t n$

"Your (pl.) nose breaths its (9m.s.) perfume. Take to yourselves the Eye of Horus, its perfume comes to you "(Richter, 2012).

\subsubsection{Kom Ombo Temple}

Currently, the laboratory of Kom Ombo temple is badly damaged (Fig.19), but there is a relief on the lintel of two sphinxes holding perfume jars (Byl, 2012) (Fig.20). 


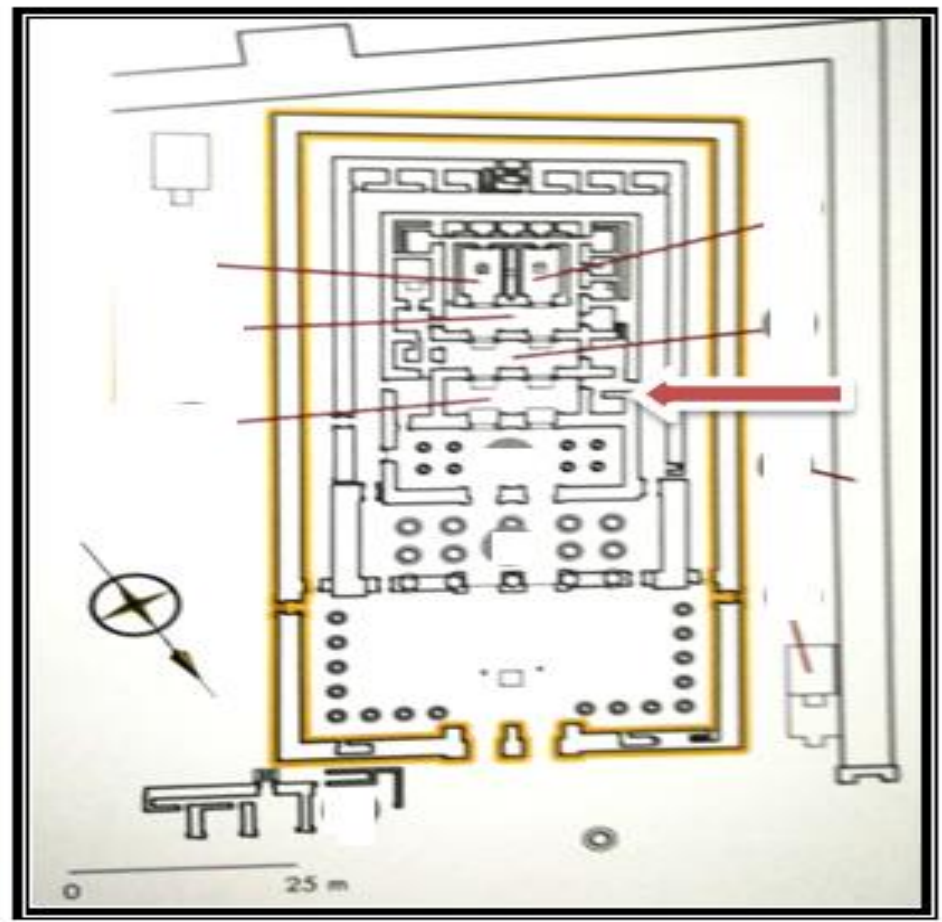

The Laboratory

Fig19. Plan of Kom Ombo temple, showing the laboratory (Weeks, 2005).

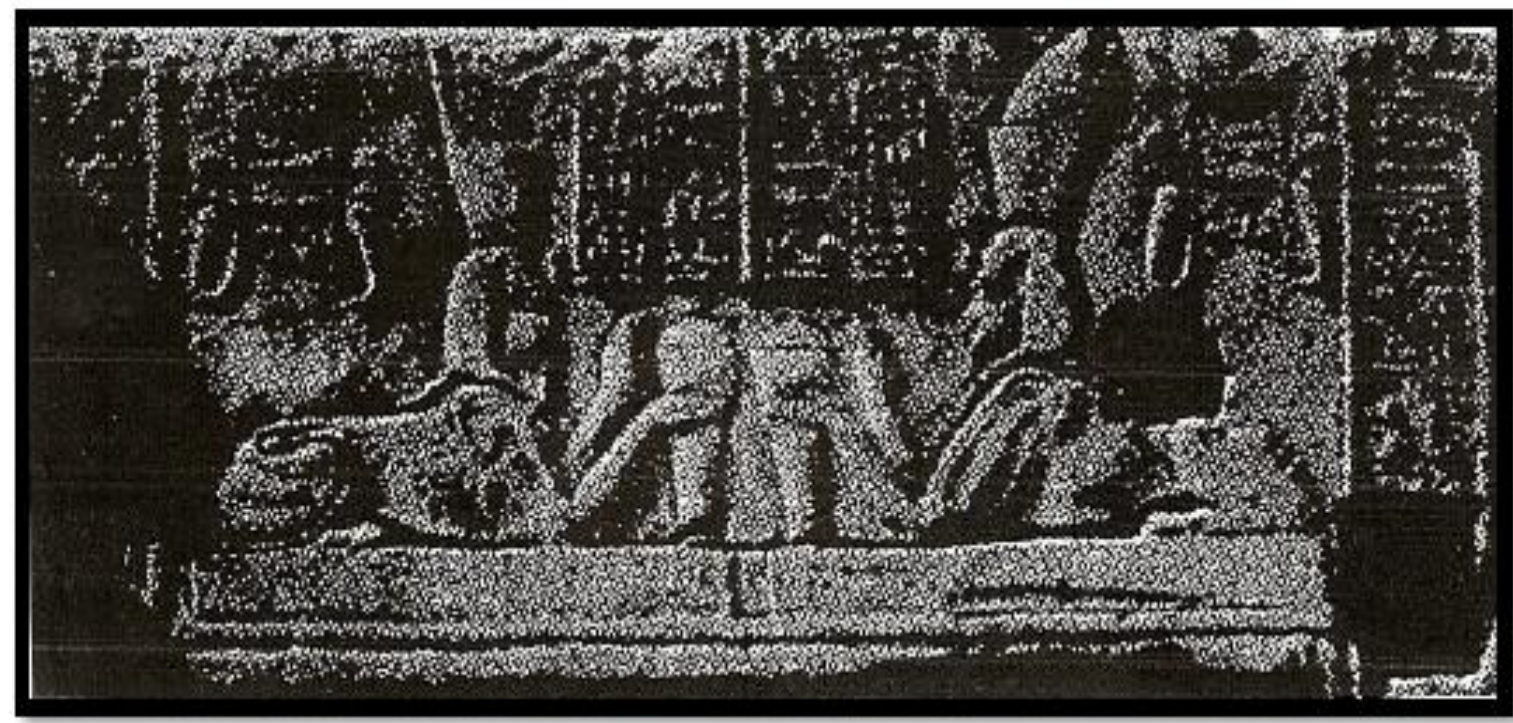

Fig20. Relief of sphinx on lintel of laboratory (Byl, 2012).

The following formula can be seen on a column in the central hall of the temple:

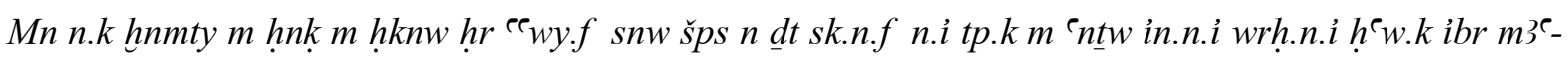
hrw.kiw.kiry.f $m$ m $\jmath^{e}$ hrw

"Take to yourself the scent offered with oil upon my hands. August image of Djet. I anoint your head with myrrh; I bring unguent for your body and perfume. May you be justified, you belong to him as one justified"(Metwally, 2009).

\subsection{Tombs}

Although the manufacture of scent was a major industry in Egypt but no production centers have been unearthed in the tombs as well as it was hardly ever included in the tomb decorations (Manniche, Perfume, 2009) (Fig.21). In the meantime, a perfumers' workshop is depicted on a wall in the Theban tomb TT 175 in El-Khokha Necropolis, showing workers crush herbs, add them to a melting bowl, then shape them into balls (Janick, 2002; Byl, 2012) (Fig.22). 


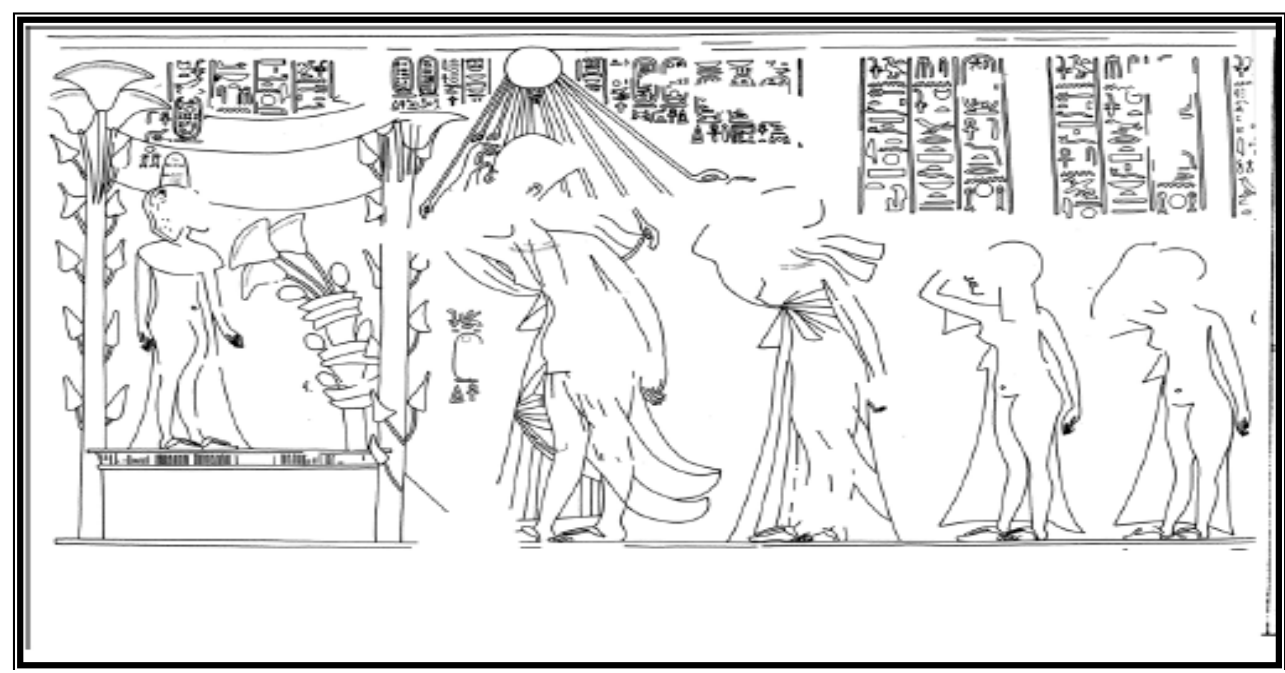

Fig21. Scene in the Amarna Royal tomb, showing princess Meketaten, who is wearing a head cone (Stevens, Rogge, Bos, \& Dabbs, 2019).

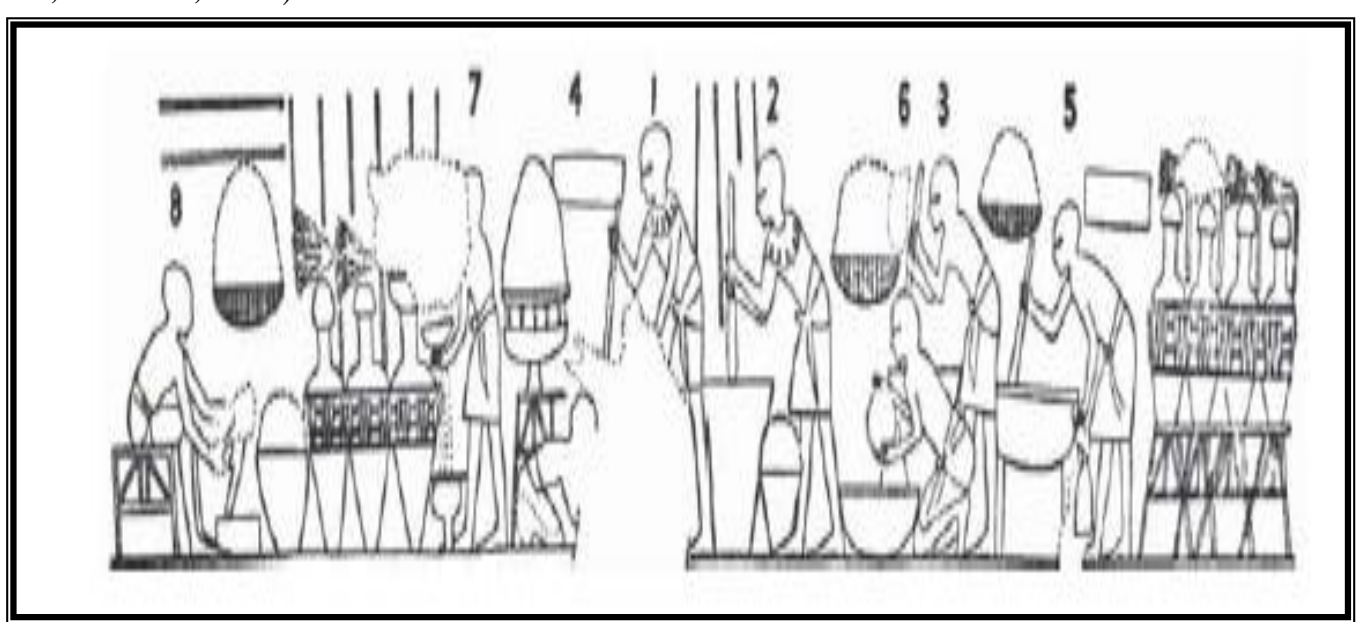

Fig22. Scene of perfume workshop, Theban tomb TT 175, El-Khokha (Janick, 2002; Byl, 2012)

\subsubsection{Tombs of Petosiris at Tuna El-Gebel Necropolis}

Meanwhile, Tuna El-Gebel is one of the most important necropolises in Egypt (Zoair, 2018; Fassbinder, Lambers, \& Flossmann-Schütze, 2015) as well as it was the Greco-Roman cemetery of Hermopolis Magna (Subias, Fiz Fernández, Carruesco, Azara, \& Cuesta, 2011) the $15^{\text {th }}$ Nome "wnt " of Upper Egypt therefore this tomb reflects the interaction of both Greek and Egyptian religious beliefs (Zoair, 2018). Also the tomb of Petosiris dates back to the last quarter of the fourth century BC and Petosiris was high priest of Thoth at Hermopolis Magna (Venit, 2016). Besides in the tomb of Petosiris, scenes of daily life, such as preparing perfumes are shown (Sales, 2016; Lacovara, 2016; Romanis \& Maiuro, 2011) with reliefs painted in vivid colors (O'Connell, 2014) (Fig.23).

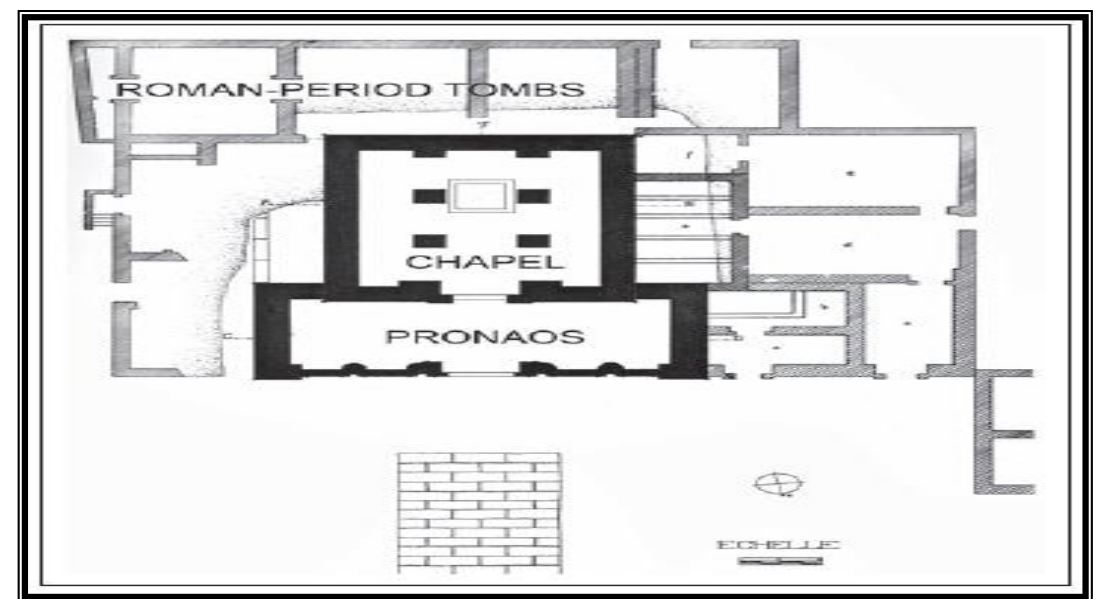

Fig23. Plan of tomb of Petosiris, Tuna El-Gebel (Venit, 2016; Sales, 2016). 
In other word, on the northern wall to the east of the gate, there are scenes of perfume makers (Sales, 2016). Indeed, in the top register, a worker of perfume overturns a wide-mouthed vessel, pouring red berries onto the ground. Also behind him, one man picks through the berries, while another works on hulling the fruit. After all, in the lower register, the workers are stoking the fire in an oven and stirring the contents of a pan placed in an oven (Venit, 2016; Byl, 2012; Sales, 2016) (Fig.24).

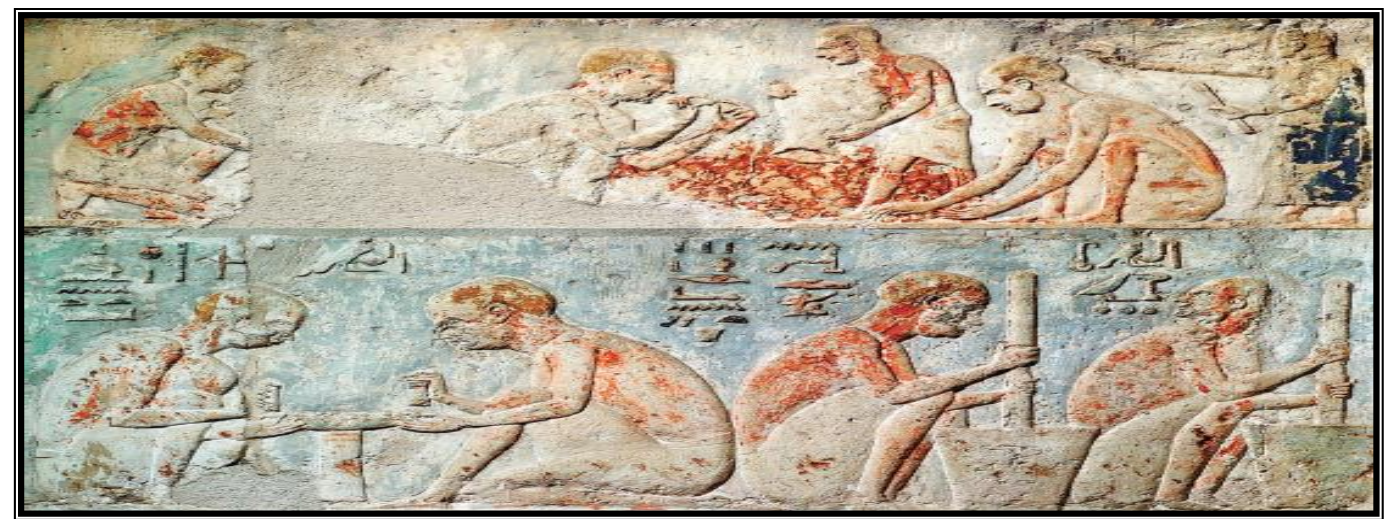

Fig24. Perfumers performing their duties (Sales, 2016).

Additionally, in another scene, a man is seated so as to smell the contents, then pouring perfume into a jar under the watching eye of an overseer, and finally carrying two vessels to a man who is seated (Byl, 2012; Lacovara, 2016; Sales, 2016) (Fig.25). Also the married couple "Petosiris and his wife" is wearing wigs and their heads support perfumed cones (Venit, 2016). While, in GB 35 in the Necropolis of Petosiris, the flasks contained oil or perfumes for sacrifices (Lembke, 2018) (Fig.26).

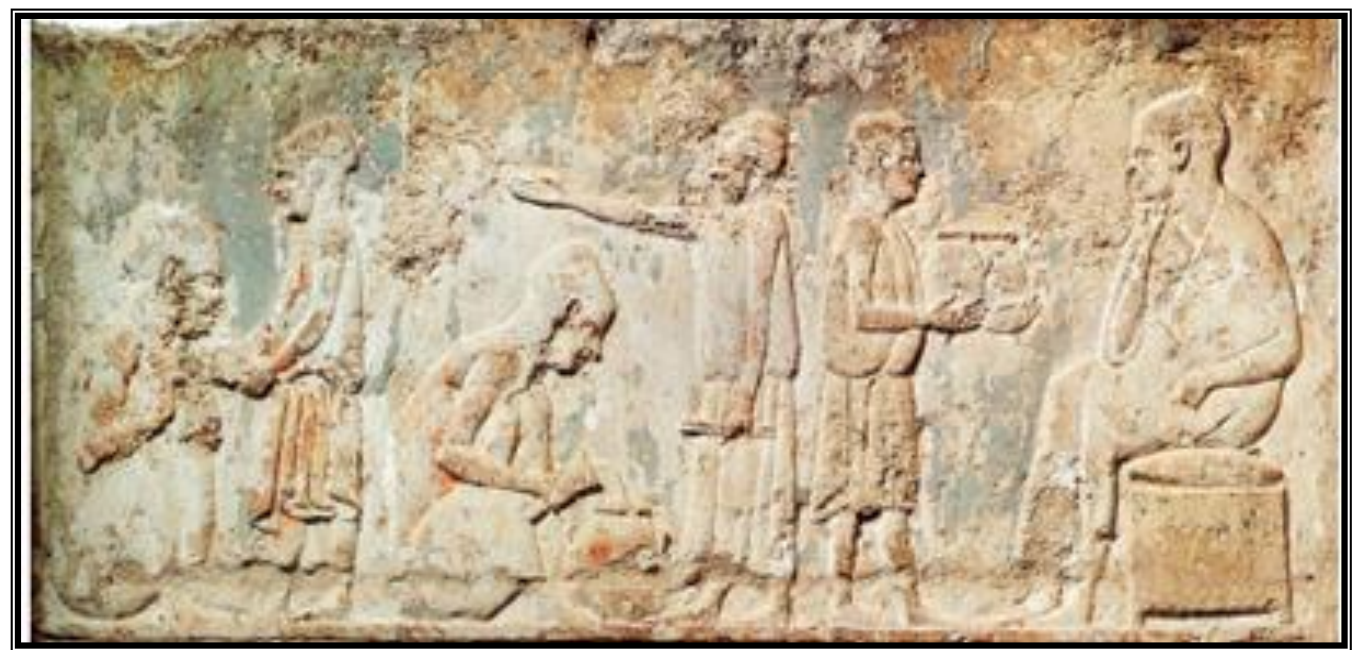

Fig25. Perfumers preparing perfume (Sales, 2016; Byl, 2012)).

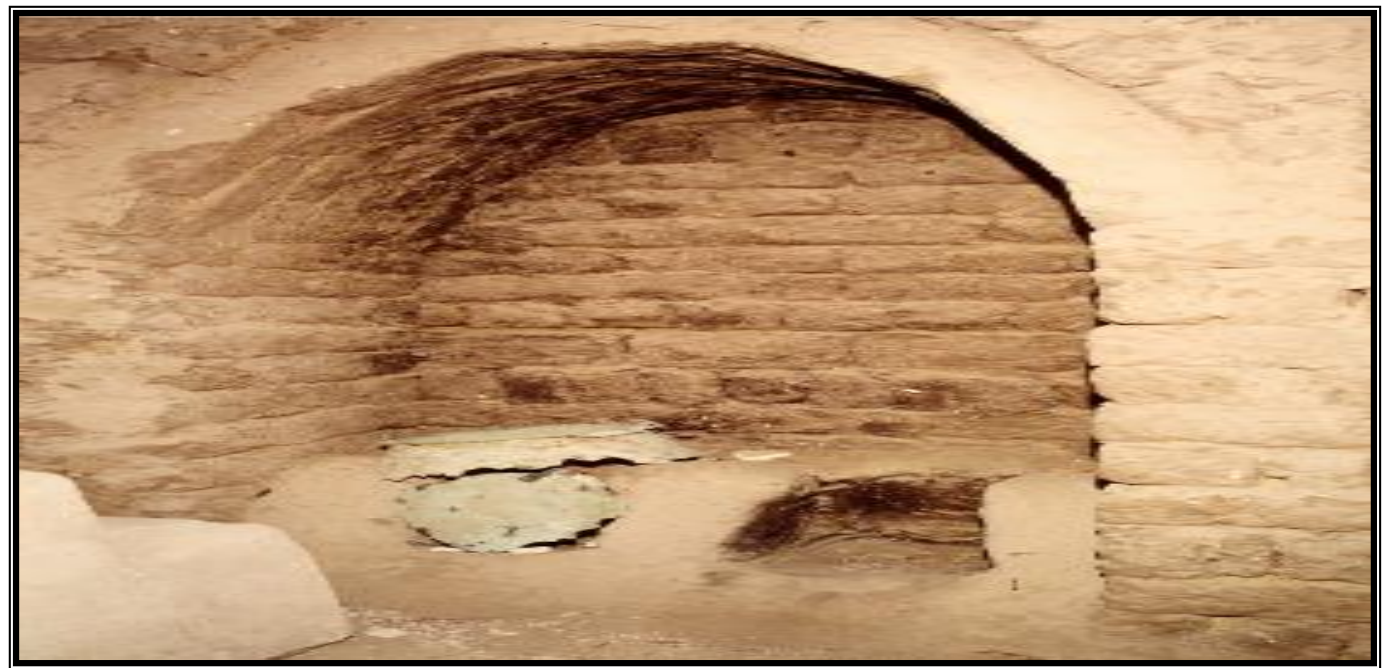

Fig26. Fireplace at GB 35, Petosiris necropolis (Lembke, 2018). 


\subsubsection{Tomb of Petosiris at Mazawka Necropolis, Dakhla oasis}

While the tomb of Petosiris at the Mazawka Necropolis was elaborately painted (Boozer, 2013). The tomb dates back to the first century AD, with two artistic styles: Egyptian and Hellenistic-Roman (Minas-Nerpel, 2007). In addition to, there is a scene on the western wall of the antechamber of Petosiris tomb, depicting seven gods in different figures, such as the sons of Horus and the goddess $w d 3 t$ who holds an incense flame in her left hand and a scepter in her right (Omran \& Zouair, 2014) (Fig.27).

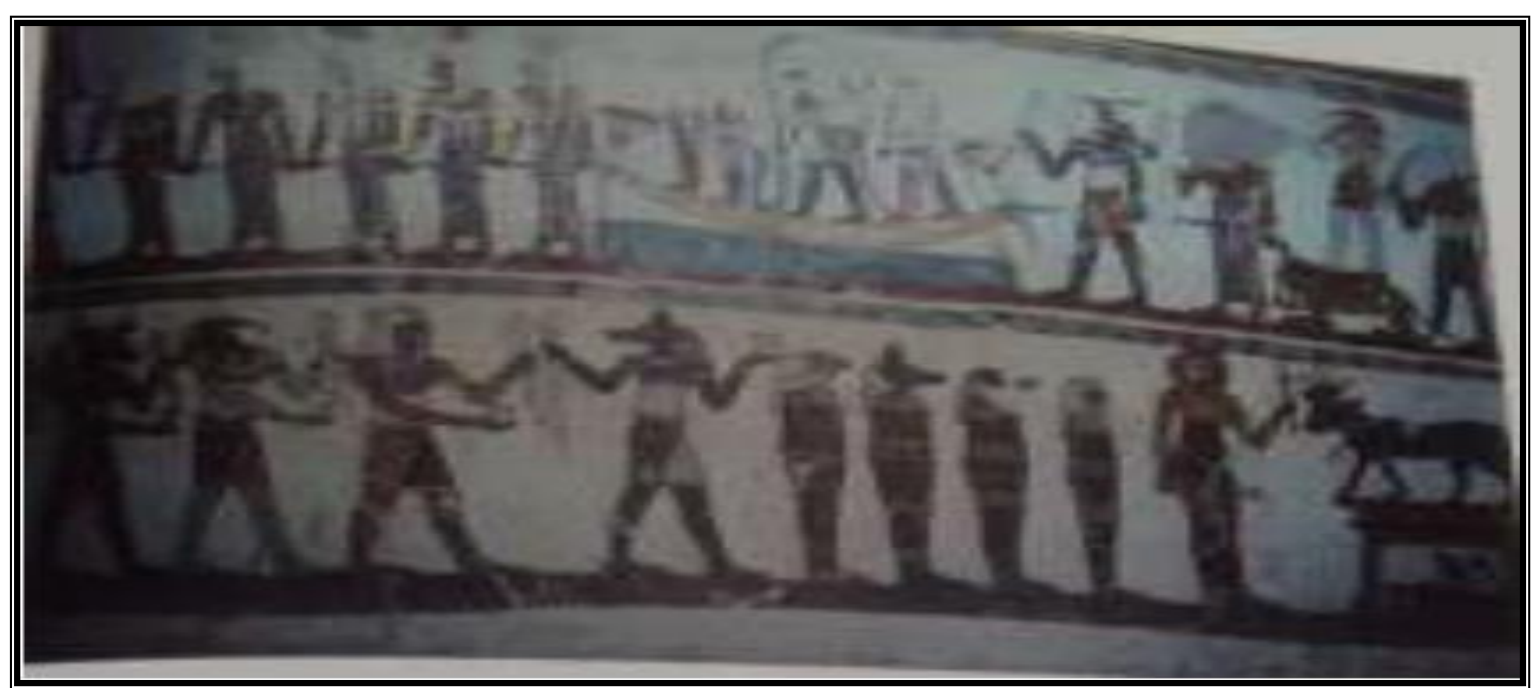

Fig27. The tomb of Petosiris at Mazawka Necropolis (Omran \& Zouair, 2014).

\subsection{Vessels and Containers Used for Perfumes in Ancient Egypt}

Meanwhile various materials were used to make perfume containers, such as alabaster, porcelain, glass, stone (Gadea, Vatca, \& Vatca, 2017), faience, onyx, ivory, and bone (Figs.28-29) (Ruiz, 2001), and sometimes gold (Gadea, Vatca, \& Vatca, 2017). As well as The fragrances were stored in several types of containers, for instance, cosmetic spoons in the form of a swimming girl that were used from the early New Kingdom to the Christian period (d'Avennes, 2000; Ruiz, 2001) (Fig.30). Additionally, white clay was imported from Edfu to make small bottles, while ceramic bottles were made with local Nile silt (Zermani \& Nawar, 2015).

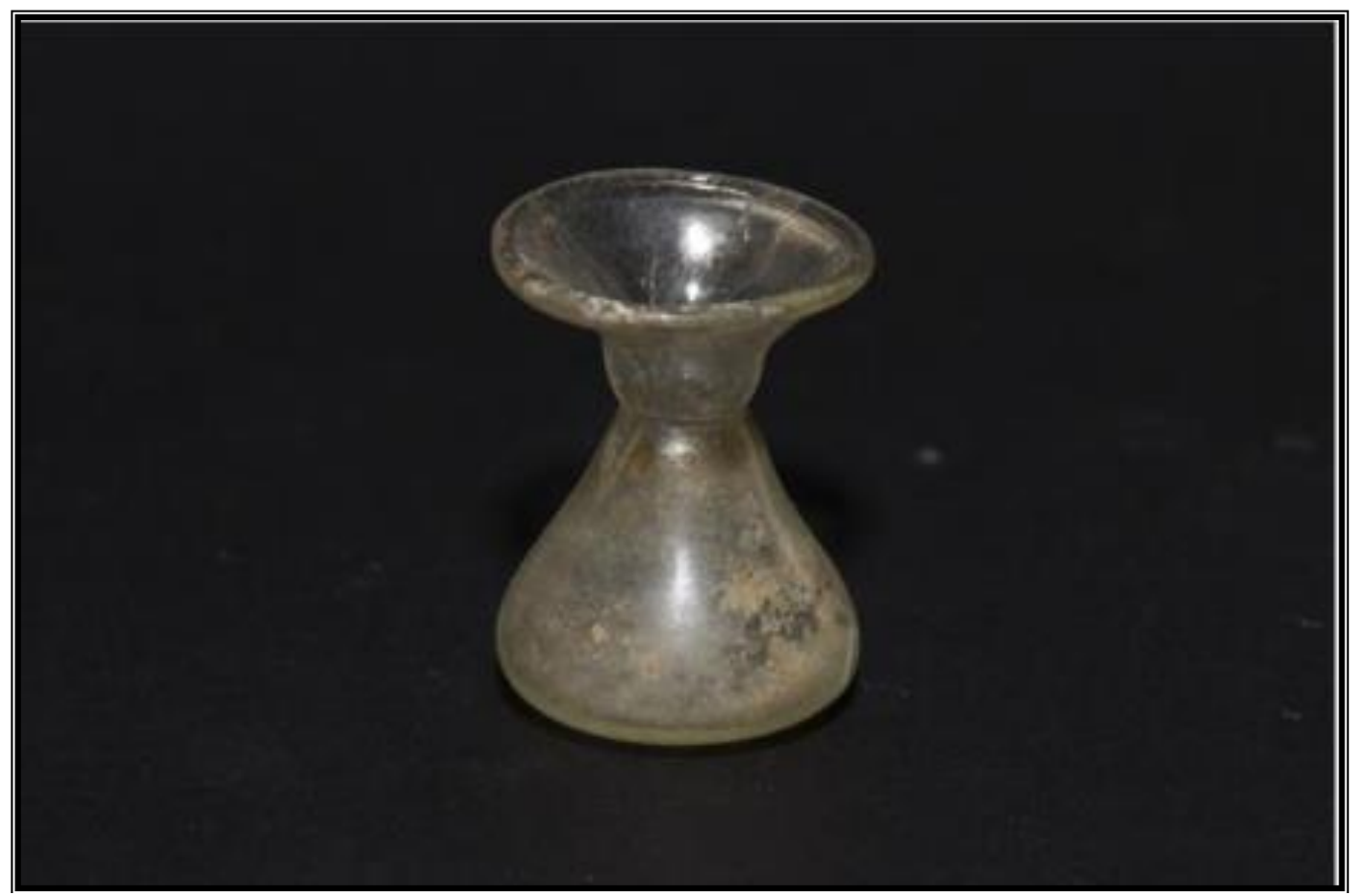

Fig28. Perfume flask, Roman period " $2^{\text {nd }}$ to $3^{\text {rd }} A D$ ", Fyoum, glass (http://antiquities.bibalex.org/Collection/ Detail.asp $x$ ?lang $=$ en $\& a=178$ ) 


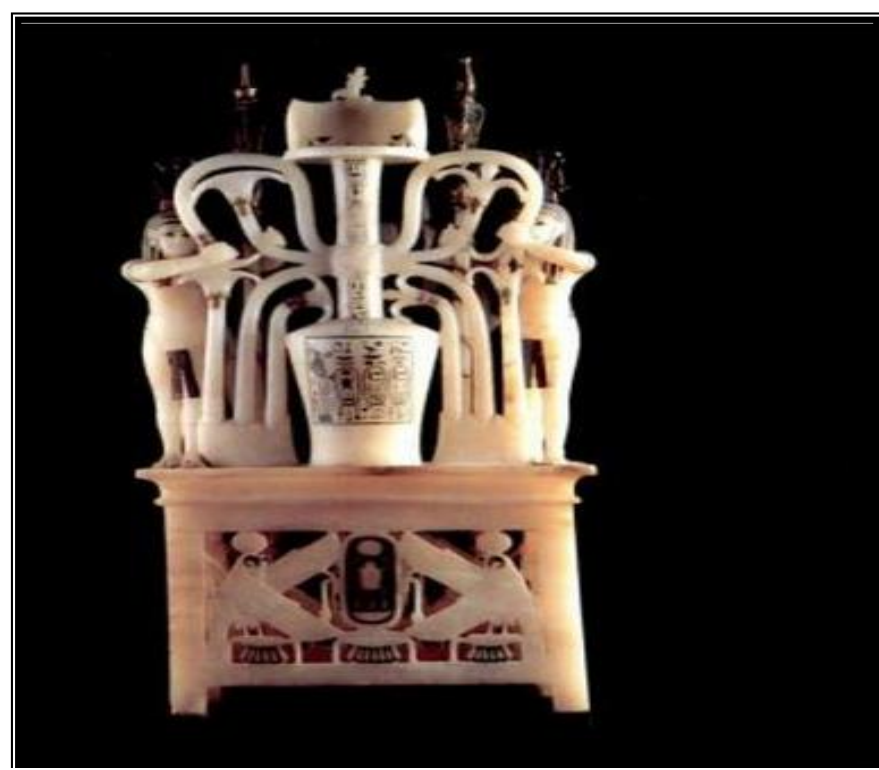

Fig29. Perfume vessel, 18 ${ }^{\text {th }}$ Dynasty "New Kingdom”, Upper Egypt, alabaster (El-Shahawy, 2005; Hassaan, 2017)

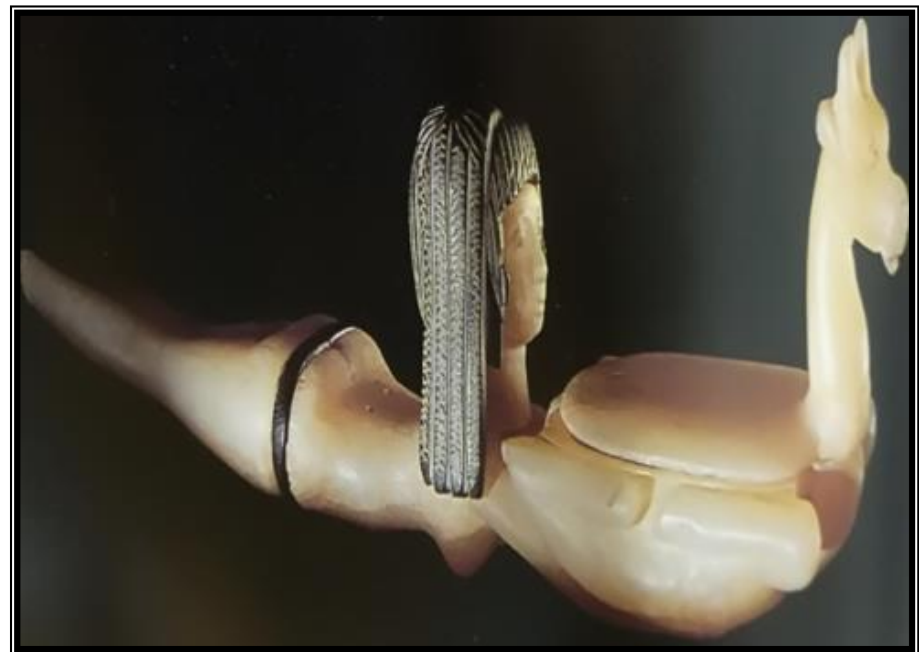

Fig30. Cosmetic spoon in the form of a swimming girl (Manniche \& Forman, Egyptian Luxuries: Fragrance, Aromatherapy, and Cosmetics in Pharaonic Times, 1999; d'Avennes, 2000)

Specifically, from the earliest times, there are perfume jars and other vessels decorated with wavy lines. Also the earliest glass factory found in Egypt can be dated to the reign of Amenhotep III at Thebes, and in Roman times, Alexandria became one of the world's greatest glass manufacturing centers (Figs.31-33) (David, 2007; Killen, 1994).

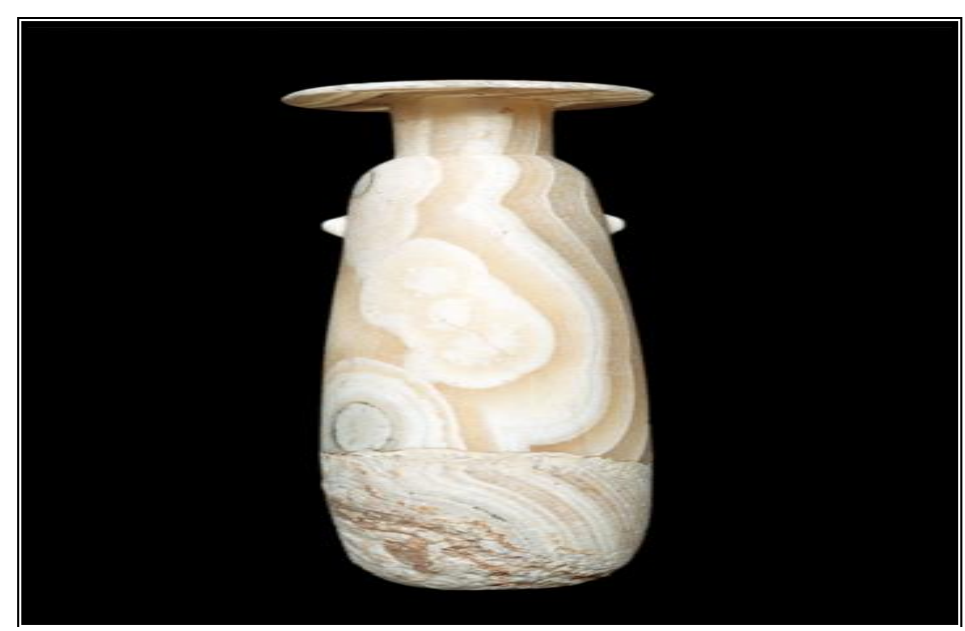

Fig31. Small perfume flask, Greco-Roman period, rock-alabaster (http://antiquities.bibalex.org/Collection/ Detail.aspx?lang =en $\& a=178 ; b ;$ Fayed, 1998) 


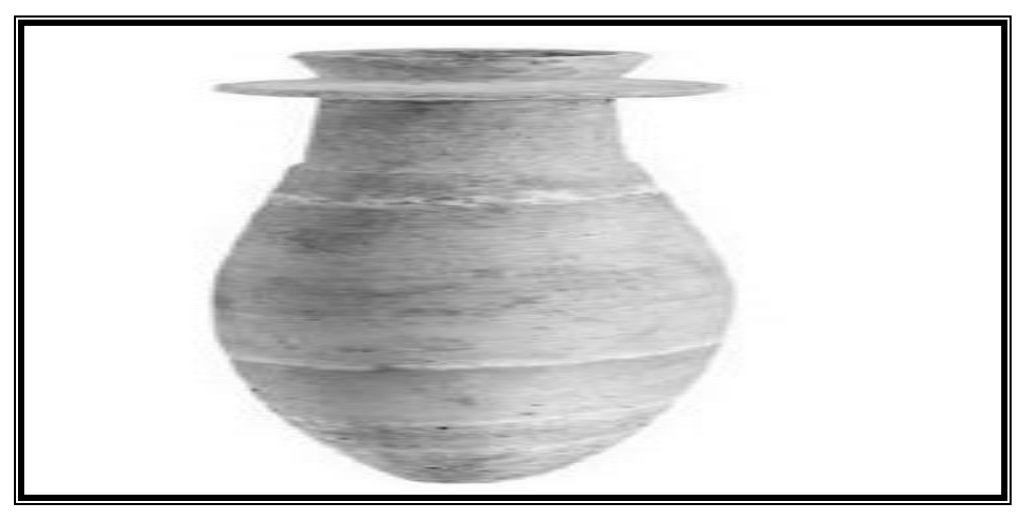

Fig32. Small perfume flask, late Ptolemaic / early Roman period, alabaster (Kalloniatis, 2019)

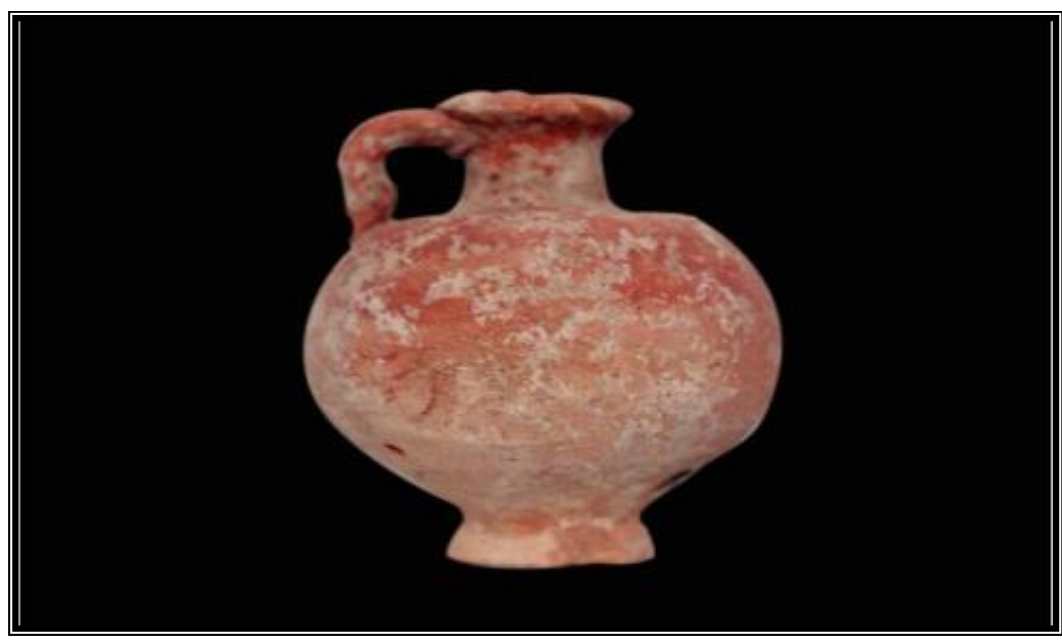

Fig33. Perfume flask, Ptolemaic period, Alexandria, "terracotta" pottery (http://antiquities.bibalex.org/Colle ction/Detail.aspx?lang $=$ en $\& a=178 ;$ Sales, 2016)

\section{DisCUSSION AND CONCLUSIONS}

As the research has demonstrated, during the Ptolemaic and Roman times, perfume was used as a part of daily life for both men and women as marriage and festive dinners and religious rituals such as offering to the gods and embalming the dead. Cult statues of the gods were anointed with perfumed oil in the daily temple ritual by the priests.

Egyptian perfumery was famous through the ancient world and occupying a central role in ancient Egypt's economy so Egypt exported perfume from Mendes and Alexandria in the Ptolemaic times to all over the Mediterranean. Although most of the surviving recipes for perfume dated back to the Greco-Roman period but the perfume was used from Predynastic period in Egypt.

Men and women were represented with solid perfume cones in their hair from the early New Kingdom to rebirth, fertility and afterlife. The Greeks and Romans used the perfumes at all their public festivals, religious ceremonies, makeup, hygiene routines and the Egyptian influence of perfume became prevalent during Ptolemaic times.

The ancient Greeks imported the ingredients of perfume production from Egypt such as lily, lotus and palm oil. The ancient Egyptians used various types of perfumes which named in the earliest offering lists and recipes in the pyramid texts, as well as tombs, temples, coffin inscriptions and funeral papyri. Recipes of perfumes were written not only in Greek, but also in Egyptian Hieroglyphs on the walls of perfume "laboratories" in the temples where Greco Roman temples had storerooms for the preparation of incense and perfumed oils for example, Edfu temple, Philae temple and Dendera temple. The Romans devised containers for their perfumes, which could be in solid, liquid, or powder form. In the Ptolemaic period, perfumes' workshops were linked to larger production centers such as bakeries and weaving shops also there are scenes of perfumers performing at tombs such as tombs of Petosiris at Tuna El-Gebel necropolis and tomb of Petosiris at Mazawka necropolis at Dakhla oasis.

During Ptolemaic Roman times various materials were used to make perfume containers like, alabaster, glass and ivory and Alexandria became one of the world's greatest glass manufacturing 
centers such as small perfumes flask of alabaster dated back to late Ptolemaic period at Antiquities museum - Alexandria library

\section{REFERENCES}

[1] (n.d.). Retrieved October 3, 2019, from http://www.britishmuseum.org/Naukratis.

[2] (n.d.). Retrieved April 1, 2020, from http://antiquities.bibalex.org/Collection/Detail.aspx?lang =en\&a=178.

[3] Bard, K. A. (2005). Encyclopedia of the Archaeology of Ancient Egypt. New York: Routledge publication.

[4] Boozer, A. L. (2013). Archaeology on Egypt's Edge: Archaeological Research in Egypt's Dakhleh Oasis, 1819-1977. AWE Journal, 117-156.

[5] Brier, B. (2013). The History of Ancient Egypt. New York: The Great Courses.

[6] Butler, H. (2000). Poucher's Perfumes, Cosmetics and Soaps. Dordrecht: Springer Netherlands.

[7] Byl, S. A. (2012). The essence and use of perfume in ancient Egypt (Master's thesis, university of south Africa). University of South Africa theses, 1-430.

[8] Carolyn, G.-B. (2010). Dancing for Hathor: Women in Ancient Egypt. New York: Continuum publication.

[9] d'Avennes, E. P. (2000). Atlas of Egyptian Art. Cairo: The American University in Cairo Press.

[10] David, R. (2007). Handbook to Life in Ancient Egypt. New York: Oxford University Press.

[11] El-Shahawy, A. (2005). Egyptian Museum in Cairo: A Walk through the Alleys of Ancient Egypt. Cairo: Farid Atiya Press.

[12] EL-SHIMY, M. (2003). Preparation and Use of Perfumes and Perfumed Substances in Ancient Egypt. 2, pp. 29-50. Cairo: American University in Cairo Press.

[13] Erman, A. (1971). Life in Ancient Egypt. (H. M. Tirard, Trans.) New York: Dover Publications.

[14] Escoffey, C. (2012). Ancient Alexandria. Alexandrina: Bibliotheca Alexandrina Publication.

[15] Fairman, H. W. (1954). Worship and festivals in an Egyptian temple. Bulletin of the John Rylands Library, 37(1), 165-203.

[16] Fassbinder, J., Lambers, L., \& Flossmann-Schütze, M. (2015). The Hellenistic settlement of Tuna elGebel, Egypt. Archaeologia Polona, 53, 276-280.

[17] Fayed, M. (1998). The ancient Egyptian women. Cairo.

[18] Fletcher, J. (2010). Exploring the Life, Myth, and Art of Ancient Egypt (Civilizations of the World). New York: Rosen Pub Group.

[19] Gadea, S., Vatca, A., \& Vatca, S. (2017). THE HISTORY AND USE OF PERFUME IN HUMAN CIVILIZATION. Agriculture, science and practice (JASP), 3-4(103-104), 161-166.

[20] Gosse, A. B. (2007). The Civilization of the Ancient Egyptians. Montana: Kessinger Publishing, LLC.

[21] Green, P. (1996). Alexander's Alexandria. In J. Walsh, \& T. F. Reese, Alexandria and Alexandrianism (pp. 1-304). California: Christopher Hudson publication.

[22] Hassan, G. A. (2017). Mechanical Engineering in Ancient Egypt, Part 49: Alabaster Products (Predynastic to Old Kingdom Periods). International Journal of Emerging Engineering Research and Technology, 5(4), $1-13$.

[23] Hawass, Z. (2000). Egyptology at the Dawn of the Twenty-First Century. The Eighth International Congress of Egyptologists.2 "History and Religion", pp. 1-594. Cairo: The American University in Cairo Press.

[24] Heuze, G. (1862). Perfumery: Jurors' reports. London.

[25] Janick, J. (2002). Ancient Egyptian Agriculture and the Origins of Horticulture. International Society for Horticultural Science, 582, 23-39.

[26] Kalloniatis, F. (2019). The Egyptian Collection at Norwich Castle Museum: Catalogue and Essays. Oxford: Oxbow Books.

[27] Killen, G. (1994). Egyptian Woodworking and Furniture (Shire Egyptology). London: Shire press.

[28] Lacovara, P. (2016). The World of Ancient Egypt: A Daily Life Encyclopedia. California: Greenwood press.

[29] Lembke, K. (2018). A "beautiful burial" at Tuna el-Gebel Burial customs and commemorative culture from the Ptolemies to the Romans. Archeo Culte, 2, 1-22.

[30] Lesko, B. S. (1987). The Remarkable Women of Ancient Egypt. New York: Scribe Publications.

[31] Lucas, A., \& Harris, Ancient Egyptian Materials and Industries. New York: Courier Corporation .(2012) . .press 
[32] Manniche, L. (2009). Perfume. UCLA Encyclopedia of Egyptology, 1(1), 1-7.

[33] Manniche, L., \& Forman, W. (1999). Egyptian Luxuries: Fragrance, Aromatherapy, and Cosmetics in Pharaonic Times. Cairo: American University in Cairo Press.

[34] Mariette, A. (1890). The Monuments of Upper Egypt: A Translation of the "Itinéraire de la Haute Égypte". (A. Mariette, Trans.) Boston: Boston, J. H. Mansfield \& J. W. Dearborn.

[35] Metwally, A. A. (2009). The Central Hall in the Egyptian temples of the Ptolemaic period (Doctoral dissertation, Durham University). Durham University, 1-625.

[36] Minas-Nerpel, M. (2007). A Demotic Inscribed Icosahedron from Dakhleh Oasis. the Journal of Egyptian Archaeology, 93, 137-148.

[37] Murray, M. A. (2002). Egyptian Temples. New York: Dover Publications.

[38] Northrup, C. C., Bentley, J. H., Jr, A. E., Manning, P., Pomeranz, K., \& Topik, S. (2004). Encyclopedia of World Trade: From Ancient Times to the Present. New York: Routledge publication.

[39] O'Connell, E. (2014). Egypt in the First Millennium AD: Perspectives from New Fieldwork. Leuven: Peeters Publishers.

[40] Omran, W., \& Zouair, N. (2014). The Depiction of Apis in the Greco- Roman Tombs of Egypt. Journal of Association of Arab Universities for Tourism and Hospitality, 11(3), 44-65.

[41] Pinch, G. (1994). Magic in Ancient Egypt. London: British Museum press.

[42] Price, R. (2018). Sniffing out the Gods: Archaeology with the Senses. Journal of Ancient Egyptian Interconnections, 17, 137-155.

[43] Quack, J. F. (2013). Conceptions of Purity in Egyptian Religion. In C. Frevel, \& C. Nihan, Purity and the Forming of Religious Traditions in the Ancient Mediterranean World and Ancient Judaism (Vol. 3, pp. 115-158). Leiden: Brill publication.

[44] Redford, D. B. (2001). The Oxford Encyclopedia of Ancient Egypt (Vol. 3). New York: Oxford University Press.

[45] Remler, P. (2006). Egyptian Mythology A to Z. New York: An imprint of infobase publishing.

[46] Rhind, J. P. (2014). Fragrance and Wellbeing: Plant Aromatics and Their Influence on the Psyche. London: an imprint of Jessica kingsley publishers.

[47] Richter, B. A. (2012). The Theology of Hathor of Dendera: Aural and Visual Scribal Techniques in the Per-Wer Sanctuary (Doctoral dissertation, California University). University of California, Berkele, 1-579.

[48] Riggs, C. (2006). The Beautiful Burial in Roman Egypt: Art, Identity, and Funerary Religion. New York: Oxford University Press.

[49] Romanis, F., \& Maiuro, M. (2011). Across the Ocean: Nine Essays on Indo-Mediterranean Trade. Boston: Brill publication.

[50] Ruiz, A. (2001). The Spirit of Ancient Egypt. New York: Algora Publishing.

[51] Sales, J. D. (2016). The Decoration of the Pronaos of Petosiris' Tomb. Themes, Scenes, Styles and Techniques. Trabajos de Egíptologia. Papers on Ancient Egypt, 7, 179-201.

[52] Scalf, F. D. (2014). Passports to Eternity: Formulaic Demotic Funerary Texts and the Final Phase of Egyptian Funerary Literature in Roman Egypt. Chicago: Chicago university press.

[53] Shafer, B. E., Arnold, D., Bell, L., Finnestad, R. B., \& Haeny, G. (2005). Temples of Ancient Egypt. New York: Cornell University.

[54] Stevens, A., Rogge, C., Bos, J., \& Dabbs, G. (2019). From representation to reality: ancient Egyptian wax head cones from Amarna. Antiquity, 93(372), 1515-1533.

[55] Strong, M. E. (2018). Illuminating the Path of Darkness: Social and Sacred Power of Artificial Light in Pharaonic Period Egypt (Doctoral dissertation, Cambridge University). Cambridge University Theses and Dissertations Archive, 1-286.

[56] Subias, E., Fiz Fernández, J., Carruesco, J., Azara, P., \& Cuesta, R. (2011). The space of the city in Graeco Roman Egypt: image and reality. Tarragona: Institut Català d'Arqueologia Clàssica press.

[57] Tatomir, R. G. (2016). TO CAUSE “TO MAKE DIVINE” THROUGH SMOKE: ANCIENT EGYPTIAN INCENSE AND PERFUME. AN INTER- AND TRANSDISCIPLINARY RE-EVALUATION OF AROMATIC BIOTIC MATERIALS USED BY THE ANCIENT EGYPTIANS. Muzeul Brailei "Carol I", 683-696.

[58] Toller, V., S., C., \& Dodd, G. (1993). Fragrance. London: Springer Netherlands.

[59] Veiga, P. (2009). Health and Medicine in Ancient Egypt: Magic and Science. Bar Archaeopress.

[60] Venit, M. S. (2016). Visualizing the Afterlife in the Tombs of Graeco-Roman Egypt. New York: Cambridge University Press. 
[61] Voudouri, D., \& Tesseromatis, C. (2015). Perfumery from Myth to Antiquity. International Journal of Medicine and Pharmacy, 3, 41-55.

[62] Watts, E. W. (1998). Art of Ancient Egypt: A Resource for Educators. New York: Metropolitan Museum of Art press.

[63] Weeks, K. R. (2005). The Illustrated Guide to Luxor: Tombs, Temples, and Museums. Cairo: The American University in Cairo Press.

[64] Wilfong, T. (2013). Life, Death and Afterlife in Ancient Egypt: The Coffin of Djehutymose in the Kelsey Museum of Archaeology. Michigan: Kelsey Museum of Archaeology publication.

[65] Wilkinson, R. H. (2000). The Complete Temples of Ancient Egypt. London: Thames \& Hudson publication.

[66] Willy, C. (2010). Egyptian Temples and Priests: Graeco-Roman. In A. B. Lloyd, A Companion to Ancient Egypt (pp. 274-290). Oxford: blackwell publishing ltd.

[67] Zermani, I., \& Nawar, A. R. (2015). The Story of Ancient Timai. (H. S. Hindawi, Trans.) Hawaii: Isabel Zermani press.

[68] Zoair, N. (2018). The Distribution of Book of the Dead Spells' in Ptolemaic Tombs in Egypt. International Journal of Heritage, Tourism and Hospitality, 12(1/2), 43-66.

\section{AUTHOR'S BIOGRAPHY}

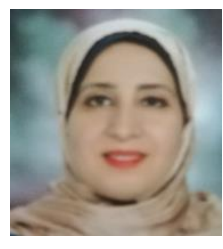

Dr. Doaa Ragab Fadel, Lecturer of Egyptian Archaeology and civilization during the Greek, Roman, and Byzantine period, at Tourist Guiding department, High Institute of Tourism\& Hotels - King Marriott - Alexandria - Egypt. Master in Tourism, Hotels, and Tourist Guiding in 2011; PhD in Tourism, Hotels, and Tourist Guiding in 2015.

Citation: Dr. Doaa Ragab Fadel. "History of the Perfume Industry in Greco-Roman Egypt" International Journal of History and Cultural Studies (IJHCS). vol 6, no. 4, 2020, pp. 26-45. doi: DOI: https://doi.org/ 10.20431/2454-7654.0604003.

Copyright: (c) 2020 Authors. This is an open-access article distributed under the terms of the Creative Commons Attribution License, which permits unrestricted use, distribution, and reproduction in any medium, provided the original author and source are credited. 